\title{
The structure of the northern Agrio fold and thrust belt (37³0'S), Neuquén Basin, Argentina
}

\author{
*Fernando Lebinson"1, Martín Turienzo ${ }^{1}$, Natalia Sánchez ${ }^{1}$, Vanesa Araujo ${ }^{1}$, \\ María Celeste D’Annunzio ${ }^{1}$, Luis Dimieri ${ }^{1}$
}

\begin{abstract}
1 Instituto Geológico del Sur (INGEOSUR), Universidad Nacional del Sur-CONICET, San Juan 670, 8000 Bahía Blanca, Argentina. fernando.lebinson@uns.edu.ar; turienzo@uns.edu.ar; natalia.sanchez@uns.edu.ar; vanesa.araujo@uns.edu.ar; celeste.dannunzio@uns.edu.ar; ldimieri@uns.edu.ar
\end{abstract}

* Corresponding author: fernando.lebinson@uns.edu.ar

\begin{abstract}
The Agrio fold and thrust belt is a thick-skinned orogenic belt developed since Late Cretaceous in response to the convergence between the Nazca and South American plates. The integration of new structural field data and seismic line interpretation allowed us to create two balanced cross-sections, which help to analyse the geometry of both thick and thin-skinned structures, to calculate the tectonic shortenings and finally to discuss the main mechanisms that produced this fold and thrust belt. The predominantly NNW-SSE structures show varying wavelengths, and can be classified into kilometer-scale first order basement involved structures and smaller second, third and fourth order fault-related folds in cover rocks with shallower detachments. Thick-skinned structures comprise fault-bend folds moving into the sedimentary cover, mainly along Late Jurassic evaporites, which form basement wedges that transfer the deformation to the foreland. Thus, shortenings in both basement and cover rocks must be similar and consequently, by measuring the contraction accounted for thin-skinned structures, is possible to propose a suitable model for the thick skinned deformation. The balanced cross-sections indicate shortenings of $11.2 \mathrm{~km}(18 \%)$ for the northern section and $10.9 \mathrm{~km}(17.3 \%)$ for the southern section. These values are different from the shortenings established by previous works in the region, reflecting differences in the assumed model to explain the basement-involved structures. According to our interpretation, the structural evolution of this fold and thrust belt was controlled by major basement-involved thrust systems with subordinate influence of inversion along pre-existing normal faults during the Andean compression.
\end{abstract}

Keywords: Thick and thin-skinned structures, Balanced cross-sections, Thrust systems, Basement involvement, Andean shortenings.

RESUMEN. La estructura del sector norte de la faja plegada y corrida del Agrio (3730' S), Cuenca Neuquina, Argentina. La faja corrida y plegada del Agrio es un cinturón orogénico de piel gruesa desarrollada desde el Cretácico Tardío en respuesta a la convergencia entre las placas de Nazca y Sudamérica. La integración de nuevos datos estructurales de campo e interpretación de líneas sísmicas permitió construir dos secciones balanceadas y, de esta manera, poder analizar la geometría de las estructuras del tipo piel gruesa y piel fina, calcular los acortamientos tectónicos y finalmente discutir los principales mecanismos que formaron esta faja corrida y plegada. Las estructuras predominantemente NNOSSE muestran diferentes longitudes de onda, y pueden ser clasificadas en estructuras kilométricas de primer orden que involucran al basamento y en pliegues más pequeños de segundo, tercer y cuarto orden en la cubierta sedimentaria relacionados con fallas con despegues menos profundos. Las estructuras de piel gruesa comprenden pliegues por flexión de falla que se insertan en la cubierta sedimentaria, principalmente a lo largo de las evaporitas del Jurásico Tardío, y forman cuñas de basamento que transmiten la deformación al antepaís. En consecuencia, los acortamientos del basamento y de la cubierta deben ser similares y, por consiguiente, al medir la contracción de las estructuras de piel delgada, es posible proponer un modelo adecuado para la deformación de piel gruesa. Las secciones balanceadas indican acortamientos de $11,2 \mathrm{~km}(18 \%)$ para la sección norte y $10,9 \mathrm{~km}(17,3 \%)$ para la sección sur. Estos valores son diferentes a aquellos 
previamente obtenidos en trabajos anteriores en la región, y reflejan principalmente las diferencias en los supuestos del modelo considerado para explicar las estructuras que involucran al basamento. De acuerdo a nuestra interpretación, la evolución estructural en este cinturón corrido y plegado estuvo controlada principalmente por sistemas de corrimientos que involucran al basamento, con una influencia subordinada de la inversión de fallas normales preexistentes durante la compresión andina.

Palabras clave: Estructuras de piel gruesa y piel fina, Secciones balanceadas, Sistemas de corrimientos, Participación del basamento, Acortamientos andinos.

\section{Introduction}

The Agrio fold and thrust belt (Ramos, 1978) is part of the Southern Central Andes and it is located at the Central-Western region of Argentina (Fig. 1a). The contractional deformation in this sector began in the Late Cretaceous related to the convergence between the Nazca plate and the South American plate. The region of study is located in the Neuquén Basin, which is one of the most important oil producing sedimentary basins of Argentina. In this zone, several works on the stratigraphy and the structure have been conducted because of the scientific and economic interest due to the presence of hydrocarbon deposits (Groeber, 1929, 1946; Zöllner and Amos, 1973; Minniti et al., 1986'; Gulisano and Gutiérrez Pleimling, 1995; Vergani et al., 1995; Kozlowski et al., 1998; Zapata et al., 1999; Zapata and Folguera, 2005; Leanza et al., 2006; Zamora Valcarce et al., 2009; Rojas Vera et al., 2015; Turienzo et al., 2014, 2018; Sánchez et al., 2014, 2015).

The Agrio fold and thrust belt (FTB) was initially defined by Bracaccini (1970) as "fosa del Agrio" and is located between Chos Malal and Las Lajas cities (Fig. 1b). According to the predominance of thick or thin-skinned structures, the Agrio FTB has been divided into an inner and outer zone (Ramos, 1998). The inner zone, at the west, is characterized by basement-involved anticlines and synclines with large wavelengths. The eastern outer zone is dominated by fault-related folds with smaller wavelengths that involve the Mesozoic sedimentary sequence above a decollement level in the Late Jurassic evaporites (Viñes, 19852; Zapata et al., 2002). Thick-skinned structures have also been recognized in the outer zone from seismic subsurface information (Zapata et al., 2002; Zamora Valcarce et al., 2009).
Two main structural models have been used in order to explain the first order basement involved structures of the fold and thrust belts in the Neuquén Basin. It has been proposed that most of the Andean contractional deformation took place by the tectonic inversion of pre-existing normal faults, inherited from the Late Triassic-Early Jurassic rifting stage of the Neuquén Basin (Vergani et al., 1995; Booth and Coward, 1996; Ramos, 1998; Zapata et al., 1999; Zapata and Folguera, 2005; Zamora Valcarce, 2007; Rojas Vera et al., 2015). Other studies consider that basement-involved thrust systems, formed by low angle reverse faults produced during the Andean compression, are the most suitable structures in order to produce the observed thick and thin-skinned deformation (Minniti et al., 1986; Nocioni, 1996; Kozlowski et al., 1998; Turienzo et al., 2014, 2018; Sánchez et al., 2015; Lebinson et al., 2015a).

The study area is situated between Chos Malal city and Taquimilán town, to the west of the Neuquén Province, Argentina (Fig. 1c). The purpose of this work is to characterize the structural style of the northern segment of the Agrio FTB based on a detailed field mapping of the exposed structures. Two balanced structural cross-sections, supported by seismic data, allow the analysis of the geometry of the major structures at depth. Additionally, the kinematics of complex thin-skinned structures was reconstructed using the Fault-FoldForward software (Allmendinger, 2012 ${ }^{3}$ ), in order to visualize its sequential evolution. Restoration of the structural cross-sections allows to determine the tectonic shortenings. A comparison of these shortenings with those previously determined in surrounding areas help to discuss the influence, or lack of it, in the different structural models proposed for this sector of the Andes.

\footnotetext{
${ }^{1}$ Minniti, S.; Gutiérrez Pleimling, A.; Artega, M.; Pestalardo, F. 1986. Análisis estructural y estratigráfico de la Faja Plegada Neuquina a la latitud de 37³0', Departamentos de Ñorquin y Pehuenches, provincia de Neuquén (Inédito). Informe Gerencia General de Exploración. Yacimientos Petrolíferos Fiscales, Subgerencia de Geología, Comisión Geológica No. 1: 64 p.

${ }^{2}$ Viñes, R.F. 1985. Estilos estructurales en la faja occidental neuquina (Inédito). Yacimientos Petrolíferos Fiscales S.A: 6 p.

3 Allmendinger, R.W. 2012. FaultFoldForward.v.6. http://www.geo.cornell.edu/geology/faculty/RWA/programs/faultfoldforward-v-6.html. (last visit 16/03/2017).
} 


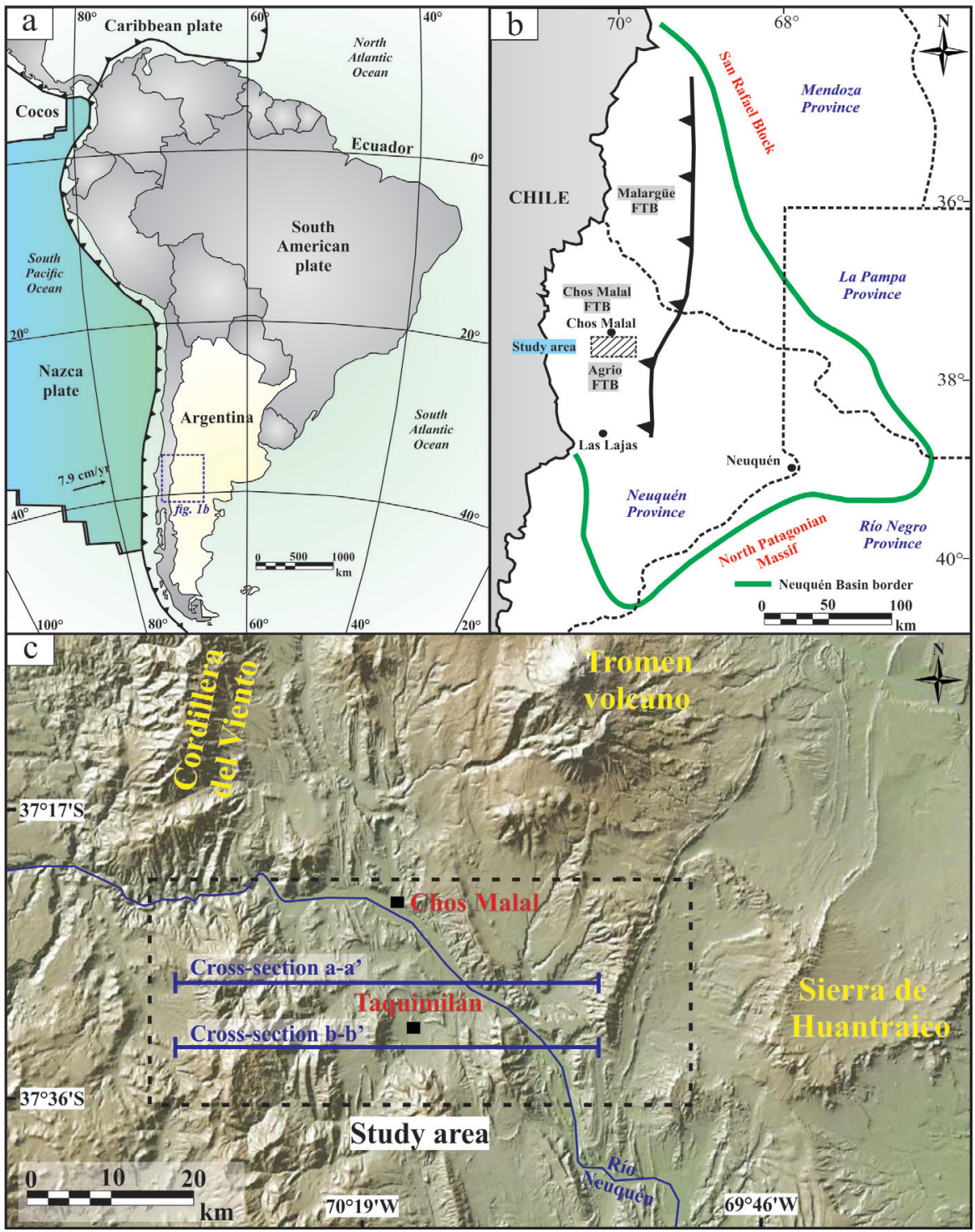

FIG. 1. a. Present-day tectonic setting at the convergent border between the Nazca and South American plates; b. Limits of the Mesozoic Neuquén Basin with the location of the Agrio, Chos Malal and Malargüe fold and thrust belts (FTB); c. Digital elevation model of the study area in the northwest of the Neuquén Province.

\section{Geological framework}

The Andes of Neuquén $\left(36^{\circ}-38^{\circ} \mathrm{S}\right.$ latitude) have distinctive characteristics due to the alternation of extensional and compressional tectonics, with important changes in its associated magmatism, developed since Late Paleozoic to Recent (Ramos, 1999; Ramos and Folguera, 2005). The development of an active margin at the western border of Gondwana during the Permian-Early Triassic produced the Choiyoi mesosilicic and silicic magmatic province (Llambías et al., 2007). According to Llambías and Sato (2011), this magmatism was favoured by the extensional collapse of the San Rafael orogen (Fig. 2). Permian granitoids of the Choiyoi Group are exposed in the Cordillera del Viento (Fig. 1c), to the north of the study area, intruding Carboniferous strata of the Andacollo Group (Zöllner and Amos, 1973; Danieli et 


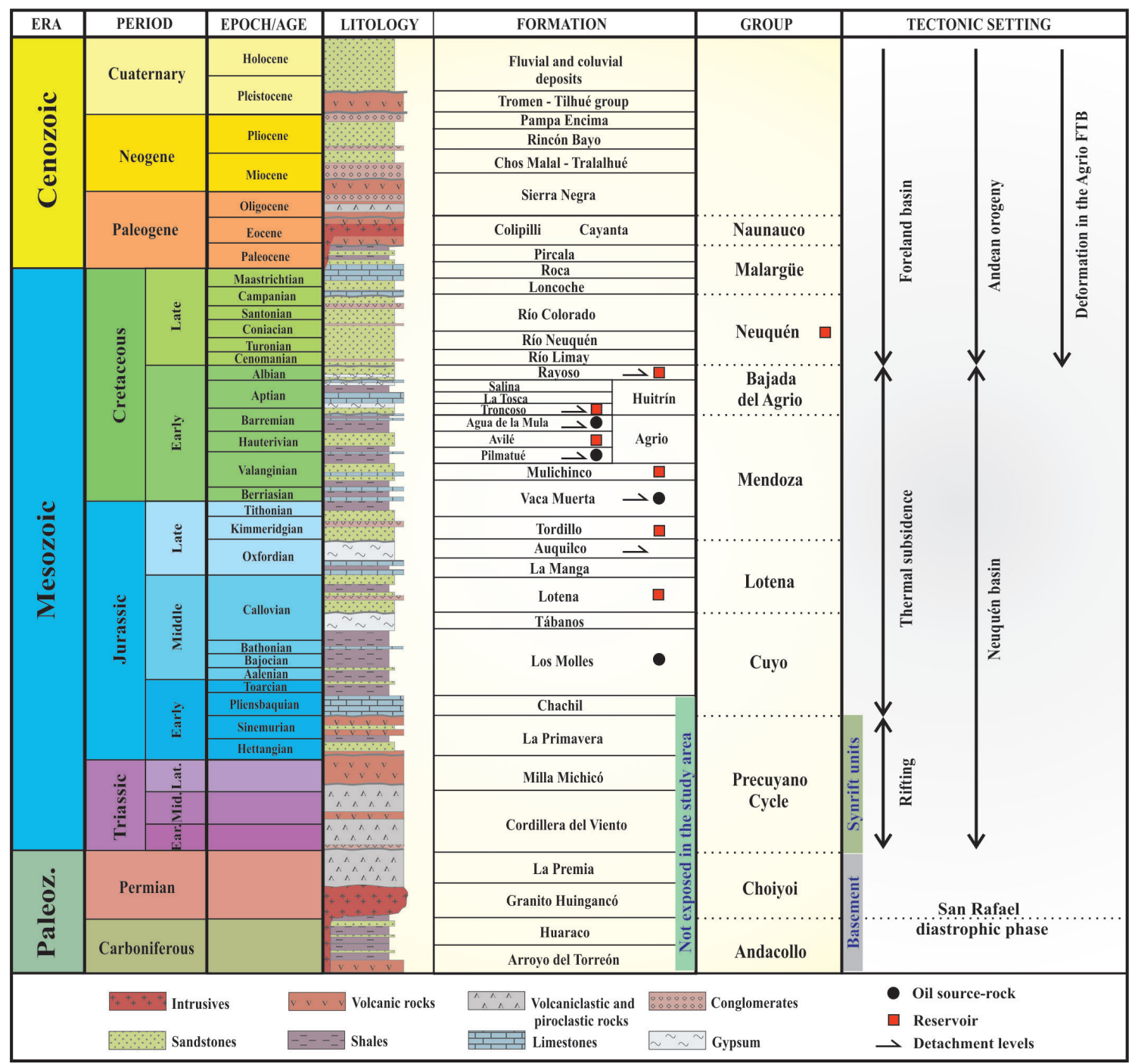

FIG. 2. Tectonostratigraphic chart of the Neuquén Basin in the study region (based on Gulisano and Gutiérrez Pleimling, 1995; Leanza et al., 2006, 2013).

al., 2011). The Late Triassic-Early Jurassic generalized extension is related with the breakup of Gondwana, that produced NW-trending half-grabens filled by volcaniclastic synrift sequences of the Precuyano Cycle (Vergani et al., 1995; Franzese and Spalletti, 2001; Carbone et al., 2011). From the Early Jurassic to the Early Cretaceous, subduction at the western margin of Gondwana caused a regional phase of back-arc thermal subsidence that favoured the accumulation of $~ 7,000 \mathrm{~m}$ of marine, continental and volcaniclastic rocks in the Neuquén Basin (Digregorio and Uliana, 1980; Legarreta and Uliana, 1996; Vergani et al.,
1995, Arregui et al., 2011). This basin has a triangular shape, limited to the northeast by the San Rafael block and to the southeast by the North Patagonian Massif (Fig. 1b), and to the west it was connected with the Pacific Ocean through the volcanic arc. The nature of the sedimentary infill during this period was controlled by a complex combination between tectonic, eustatic and climatic factors, which gave rise to transgressive-regressive marine cycles alternating with periods of continental sedimentation (Vergani et al., 1995; Legarreta and Uliana, 1996, Arregui et al., 2011). The Cuyo, Lotena, Mendoza and Bajada 
del Agrio groups were deposited during this stage of thermal subsidence (Fig. 2). Marine black shales of the Cuyo Group (Los Molles Formation) are the oldest rocks exposed in the northern Agrio FTB (Fig. 3). The overlying Lotena Group contains Late Jurassic evaporites (Auquilco Formation), which constitute one of the most important decollement horizons in the Agrio FTB (Zapata et al., 1999, 2002; Zamora Valcarce et al., 2006). The Mendoza Group includes the two most important hydrocarbon source rocks of the Neuquén Basin (Vaca Muerta and Agrio formations, Fig. 2). The Agrio Formation also contains one of the main reservoir units, the Avilé Member, formed by fluvial-aeolian sandstones that reflect a relatively major sea-level drop (Veiga et al., 2002).

Sandstones of the Lower Troncoso Member (Huitrin Formation), in the Bajada del Agrio Group (Fig. 2), are the best hydrocarbon reservoir rocks in this sector of the basin. Shallow marine rocks in this group represent the last marine connection of the Neuquén Basin with the Pacific Ocean and the subsequent deposition of continental sediments was probably influenced by the growth of the magmatic arc (Legarreta and Uliana, 1991).

Since the early Late Cretaceous, the Neuquén basin evolved into a contractional retroarc foreland basin due to the initial development of the fold and thrust belt, probably related to a combination of an increasing convergence rate (Cobbold and Rossello, 2003) and a shallowing of the Benioff zone (Ramos, 1998; Ramos and Folguera, 2005). A continental sedimentary environment prevailed in the Late Cretaceous, with the syntectonic deposition of the Neuquén Group (Tunik et al., 2010). The continuity of the flexural load allowed a marine transgression from the Atlantic Ocean represented by the shallow marine rocks of the Malargüe Group (Fig. 2). Widespread igneous rocks were derived from a subduction related magmatic arc, including the Late Cretaceous to Eocene Naunauco Group (Zamora Valcarce, 2007). Subvolcanic rocks in the Cerro Caicayén (Fig. 3), with ${ }^{40} \mathrm{~K} /{ }^{40} \mathrm{Ar}$ age of 44.7 $\pm 2.2 \mathrm{Ma}$ (Llambías and Rapela, 1989), and the Cerro Naunauco, with ${ }^{40} \mathrm{Ar} /{ }^{39} \mathrm{Ar}$ age of $65.5 \pm 0.46 \mathrm{Ma}$ (Zamora Valcarce et al., 2006), were intruded during this stage. Synorogenic foreland sequences related to Neogene contraction in the Agrio FTB accumulated in piggyback basins (Ramos, 1998; Repol et al., 2002; Zapata et al., 2002; Cervera and Leanza, 2009), are scarcely preserved in the core of synclines to the south of Chos Malal (Fig. 3). An important retroarc volcanism took place in the foreland region during the Neogene, that are evidenced by basalts, andesites and tuffs (Ramos and Barbieri, 1989; Kay et al., 2006; Dyhr et al., 2013), that in the study area form the Cerro Villegas (Fig. 3). Finally, basalts covering the Loma Tilhué correspond to lava flows coming from the Plio-Quaternary Tromen-Tilhué volcanic complex (Llambías et al., 2011).

\section{Structure}

Numerous NNW-SSE trending structures, with variable scale and vergence, are notably well exposed in the northern segment of the Agrio FTB. In several field trips, around 500 GPS points were collected, each one including geological descriptions and structural data. This field information together with georeferenced Landsat and Google Earth satellite imagery allowed us to elaborate a detailed geological map (Fig. 3), which comprises an area of $1,742 \mathrm{~km}^{2}(67 \times 26 \mathrm{~km})$. Different orders of folds were distinguished based on their wavelength and the involved units, as it was done in the Chos Malal fold and thrust belt (Kozlowski et al., 1996; Turienzo et al., 2014, 2018; Sánchez et al., 2015). The thick skinned structures form first order folds, which involve basement rocks and wavelengths of around $8-12 \mathrm{~km}$. The thin-skinned structures correspond to fault-related folds with shorter wavelengths that can be classified in second, third and fourth order depending on the detachment level within the stratigraphic pile. Based on the mapped structures and with the aid of 2D seismic profiles, two E-W balanced cross-sections were constructed in order to characterize the structural style of this segment of the Agrio FTB.

\subsection{Structures of the north sector: cross-section a-a'}

The reconstruction of the tectonic structures in depth along the north cross-section was analysed in conjunction with the information provided by seismic line 15009 (Fig. 4). Despite it's poor quality, this line shows west-dipping reflectors that allows the interpretation of the basement-cover contact geometry. The elevation of the basement-cover contact at the eastern sector of the seismic section is linked to the west-dipping Las Yeseras thrust (Fig. 4), responsible of a notable basement-cored anticline 

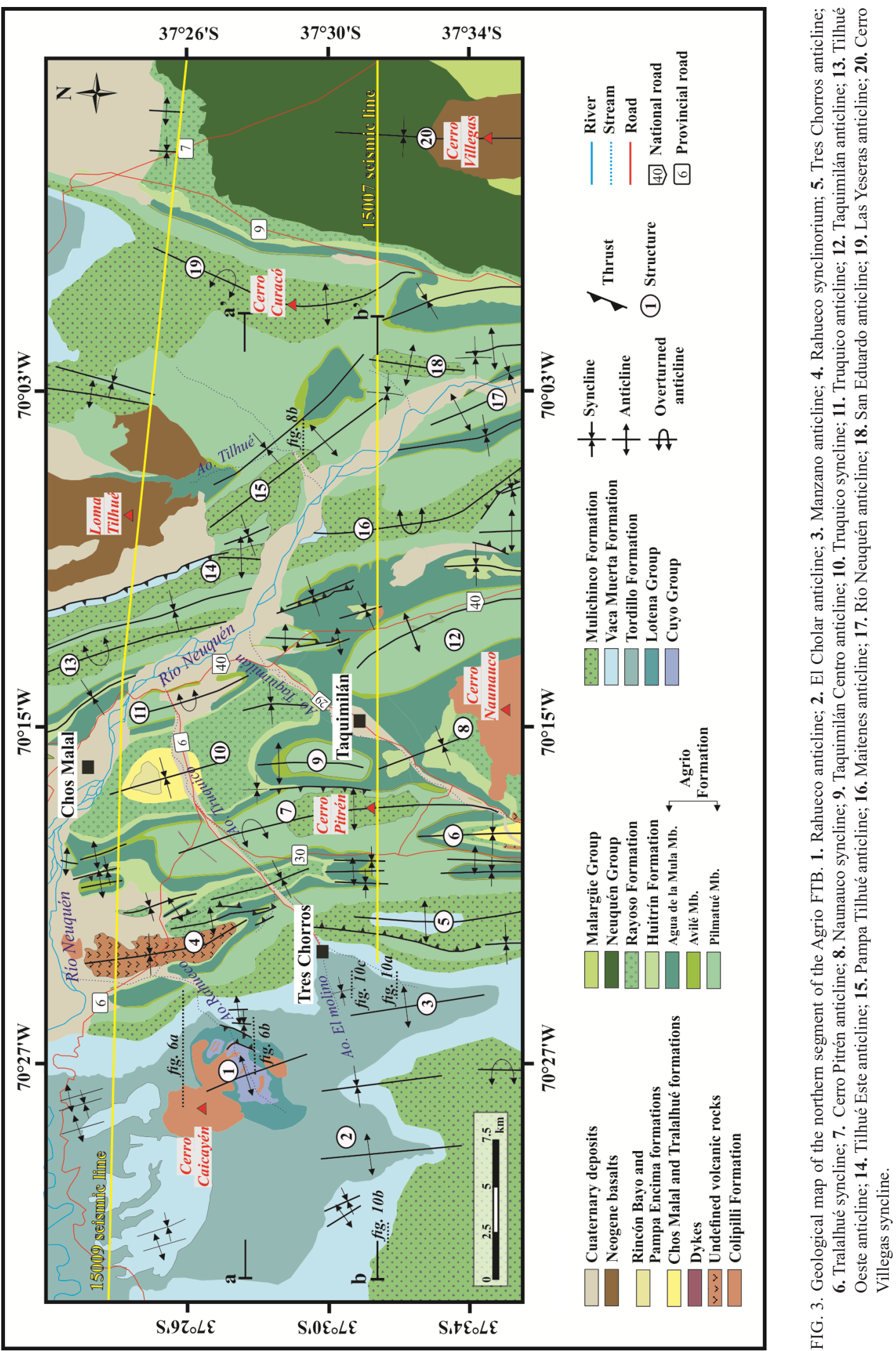


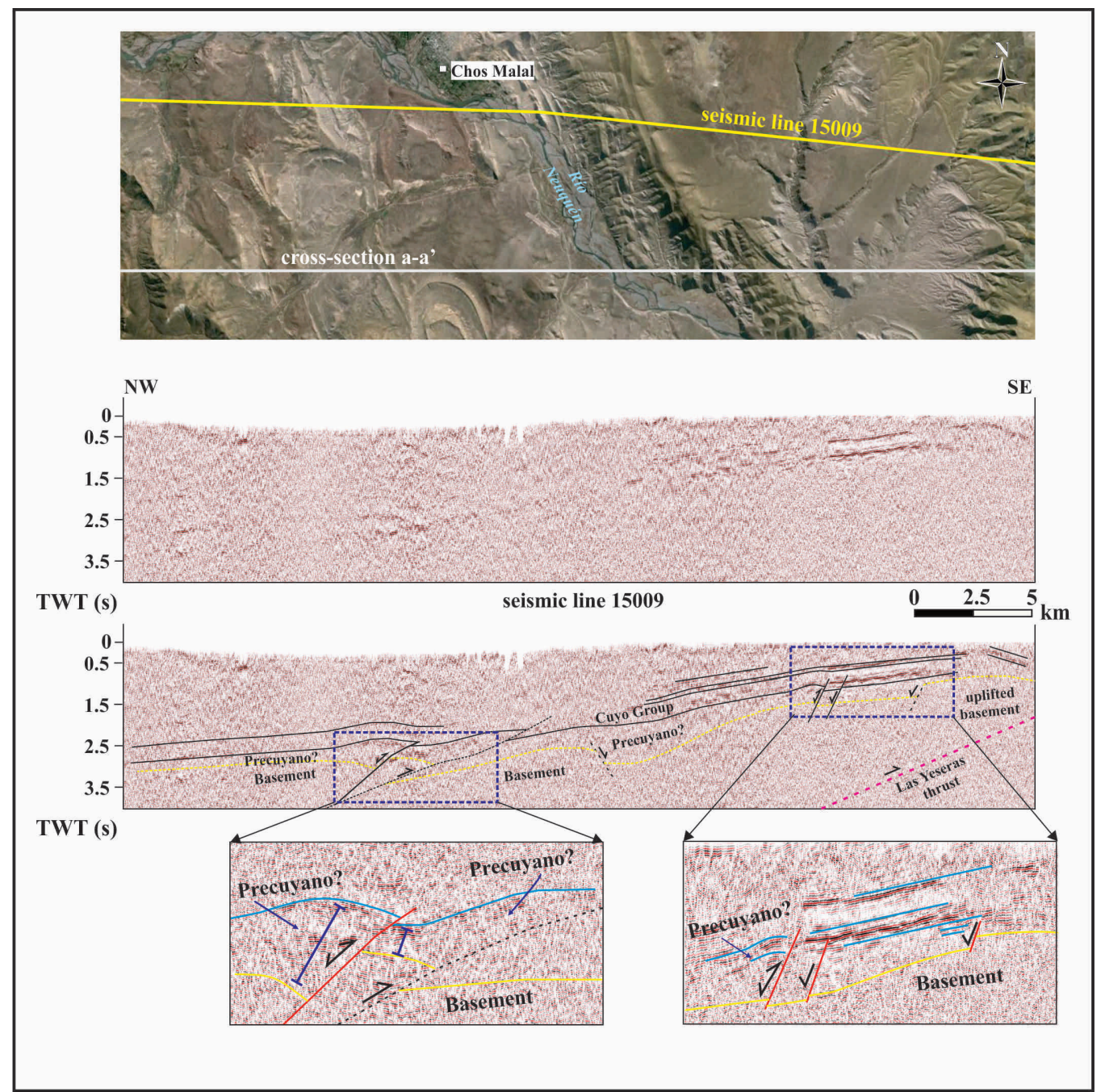

FIG. 4. Interpreted and partially interpreted two-way travel time seismic section 15009. Noticeable basement uplift at the eastern zone occurred in the hangingwall of the Las Yeseras thrust. The amplified zones depict areas in the seismic with unconfomities and varying thickness interpreted as synrift deposits related to normal faults, with scarce evidence of significant inversion.

exposed outside the studied area. Although there are no exploration wells along this seismic line, these strong and continuous reflectors can be assigned to the Jurassic sedimentary sequences. Below them, diffuse reflectors with varying thicknesses suggest the occurrence of synrift deposits of the Precuyano Cycle (Fig. 4). These synrift sequences have been related with high angle normal faults, which have been slightly inverted during the subsequent compressive deformation in the Andes. Bed-length restoration of cross-section a-a' (Fig. 5) allows to establish $11.2 \mathrm{~km}(18 \%)$ of shortening.
The westernmost structure in the north sector of the study area is the Rahueco anticline, a doubly plunging fold with an approximate wavelength of $12 \mathrm{~km}$ (Figs. 3 and 6). The Early Jurassic black shales of the Los Molles Formation, placed in the core of this anticline, correspond to the oldest rocks exposed in the Agrio FTB region (Fig. 6 a and b). Measured dips of around $15^{\circ}-25^{\circ} \mathrm{W}$ in the backlimb and $40^{\circ}$ $60^{\circ} \mathrm{E}$ in the forelimb, which increase up to $70^{\circ}-80^{\circ} \mathrm{E}$ in beds of the Mulichinco and Agrio formations (Fig. 6a), demonstrate the eastward-vergence of the Rahueco anticline. The steepening of the eastern limb is 


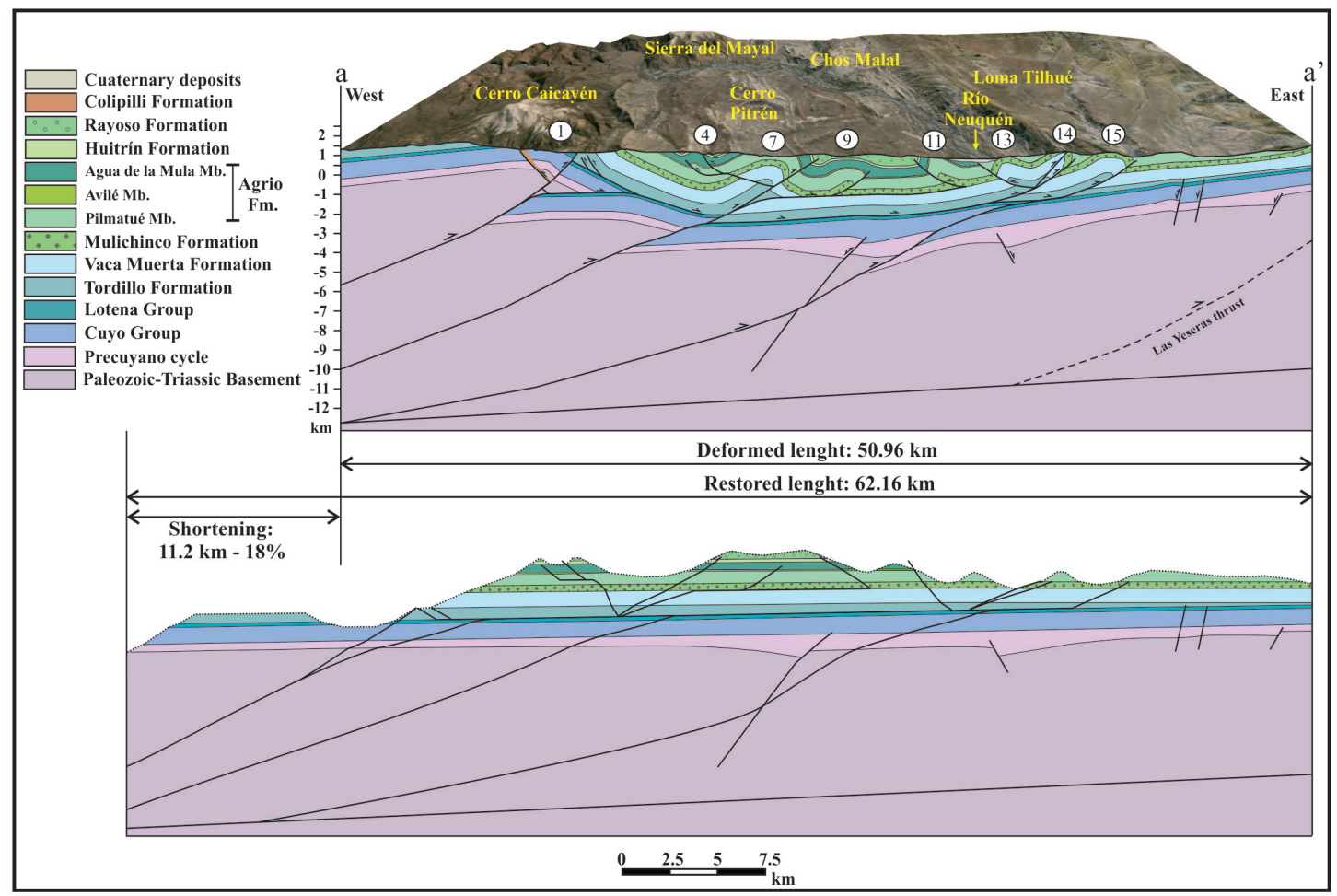

FIG. 5. Interpreted and restored structural cross-section a-a'. Major basement-involved thrusts produce first order thick-skinned wedges, which move eastward over the Auquilco Formation (Lotena Group) creating second and third order fault-related folds in the sedimentary cover. 1. Rahueco anticline; 4. Rahueco synclinorium; 7. Cerro Pitrén anticline; 9. Taquimilán Centro anticline; 11. Truquico anticline; 13. Tilhué Oeste anticline; 14. Tilhué Este anticline; 15. Pampa Tilhué anticline.

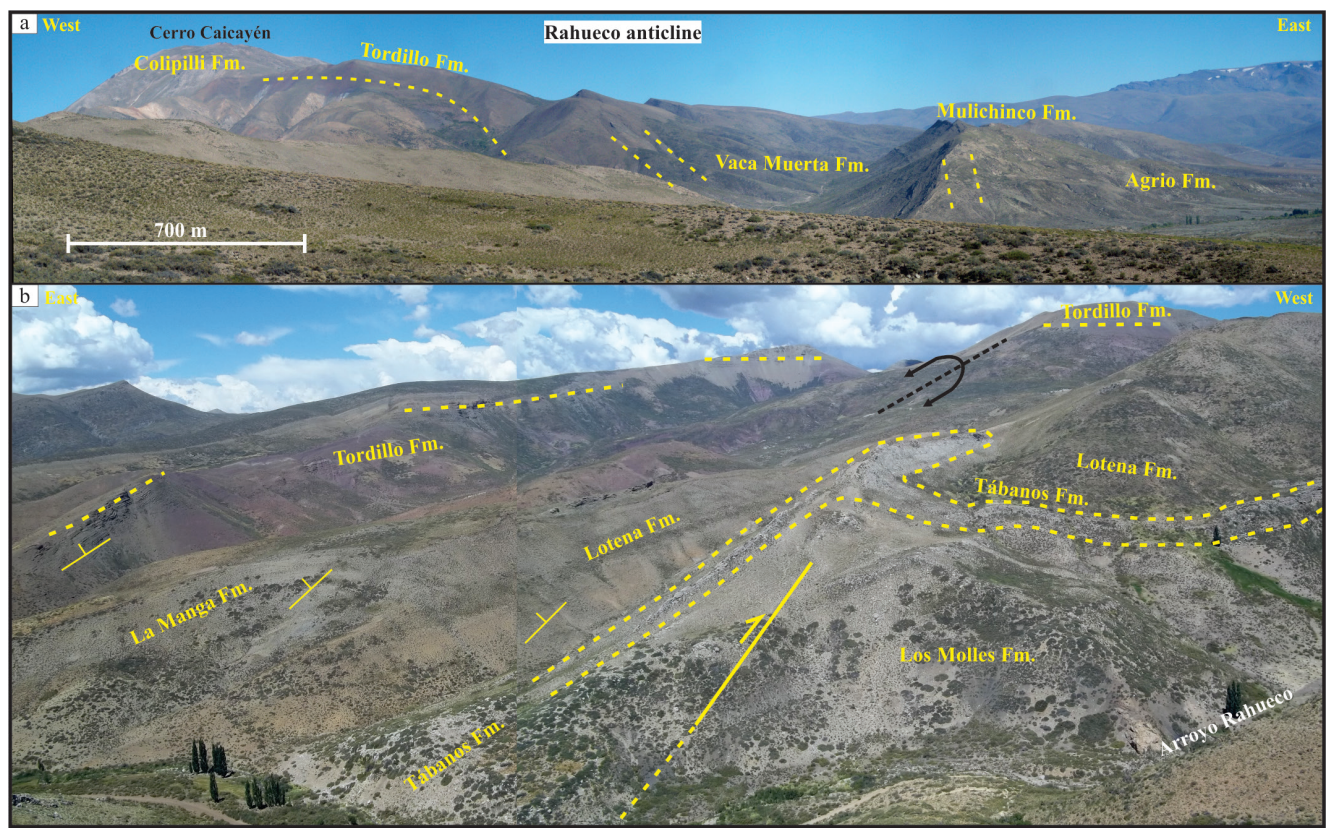

FIG. 6. a. Photograph showing the eastward-steepening of the Mendoza Group beds in the forelimb of the Rahueco anticline; b. Southward view of the backthrust and the associated west vergent fold involving the Cuyo Group in the forelimb of the Rahueco anticline. 
related to a set of minor backthrusts in the front of this major first order structure. One of these west-directed thrusts produced a tight asymmetric anticline involving the Tábanos Formation (Fig. 6b). Igneous rocks that form the Cerro Caicayén are mainly concentrated in the core of the Rahueco anticline, and were intruded using the backthrusts as feed channels (Lebinson et al., 2015b). Based on field data and the geometry of the structure, the Rahueco anticline has been interpreted as a basement wedge related to a major west-dipping thrust (Fig. 5). This tectonic wedge corresponds to a first order structure that develops as a fault-bend anticline moving along the evaporites of the Auquilco Formation and transferring shortening to the east. Thus, the thinskinned structures in the area that involve the rocks of Tordillo Formation and overlying units developed above this detachment level (Fig. 5).

The Rahueco synclinorium, located to the east of the Cerro Caicayén, is cored by gently folded volcanic rocks (of uncertain age) that cover unconformably the folded Mesozoic rocks (Figs. 3 y 7). A complex deformation occurs at the eastern limb of this synclinorium. Rocks of the Agrio, Huitrín and Rayoso formations form a tight westvergent anticline of approximately $1 \mathrm{~km}$ wavelength (Figs. 7a). Two minor backthrusts deform the Avilé Member in the core of this anticline, while in its backlimb, the Pitrén backthrust, displaces and repeats the Huitrín Formation (Fig. 7b). The average orientation of the fault plane is $092^{\circ} / 54^{\circ}$ (dip direction/ dip) with fault-striae with pitch values ranging from $5^{\circ}$ to $60^{\circ} \mathrm{S}$ and steps indicating a component of sinistral shearing for the Pitrén backthrust. To the north, near to Route 6 , there is another west-verging anticline whose backlimb and forelimb dip $45^{\circ} \mathrm{NE}$ and $64^{\circ} \mathrm{SW}$ respectively (Fig. 7a). In the core of this anticline, small thrusts repeat the Agua de la Mula Formation stratigraphy (Fig. 7c). Based on Mitra (2002), these accommodation structures were classified as intoanticline thrusts. The reconstruction of the two west-vergent anticlines in the Rahueco synclinorium allows to relate them with shallow backthrusts detached on the lower section of the Agrio Formation and classified as third order structures. Occasionally the faults associated with these third order folds reach a shallower detachment level, as the shales of the upper portion of the Agrio Formation, creating smaller-scale fourth order structures. An example of this occurs at the southern hinge of the
Rahueco syncline, where a small backthrust generated a repetition of the Huitrín Formation (Fig. 7a).

One of the most important thin-skinned folds in the study area is the Cerro Pitrén anticline (Cervera and Leanza, 2009), a doubly-plunging fold cored by the Mulichinco Formation with a wavelength of approximately $6 \mathrm{~km}$ (Fig. 3). The western limb of the Cerro Pitrén anticline has variable dips $\left(30^{\circ}\right.$ $50^{\circ} \mathrm{W}$ ), while the eastern limb is steep, or even overturned, defining a clear east vergent structure. The development of the Cerro Pitrén anticline is interpreted as a second-order fault-bend fold, with a lower detachment in the Auquilco Formation and an upper decollement on top of the Vaca Muerta shales (Fig. 5). Thus, there is a transference of displacement to the east over the upper decollement, which allows to generate third order folds involving the Mulichinco and Agrio formations (Taquimilán Centro and Truquico anticlines). Subsequently, the forelimb of the Cerro Pitrén anticline is cut by a breakthrough thrust that causes an increase in its dip. A comparable model of structural evolution has been applied in the Chos Malal FTB (Turienzo et al., 2014; Sánchez et al., 2015).

The Taquimilán Centro anticline, located to the east of the Cerro Pitrén, has a wavelength of approximately $3.5 \mathrm{~km}$ and N-S trend (Fig. 3). The west limb dips $42^{\circ} \mathrm{W}$ while the eastern one dips $75^{\circ} \mathrm{E}$, thus the vergence of the fold is to the east. An N-S thrust rides the Cerro Pitrén anticline over the backlimb of the Taquimilan Centro anticline, juxtaposing the Mulichinco Formation on top of the Agua de la Mula Member (Agrio Formation). The morphology of the Taquimilán Centro anticline allows to interpret it as a fault propagation fold detached above the shales of the Vaca Muerta Formation (Fig. 5).

The Truquico syncline, located to the south of Chos Malal, is a broad NNW trending syncline cored by Cenozoic rocks (Fig. 3). The Miocene synorogenic strata of the Chos Malal Formation lie unconformably over the Rayoso Formation and they are, in turns, covered by a thin horizontal sequence assigned to Rincón Bayo and Pampa Encima formations (Cervera and Leanza, 2009). The Truquico syncline is located into a triangle zone formed between the east-vergent Cerro Pitrén anticline and the west-vergent Truquico anticline (Fig. 5). The Truquico anticline, which is exposed at the intersection of Routes 40 and 6, has a marked west vergence and a wavelength of approximately $4 \mathrm{~km}$ (Fig. 3 ). The forelimb dips $80^{\circ}$ $85^{\circ} \mathrm{W}$, and the uppermost beds of the Agrio, Huitrín 


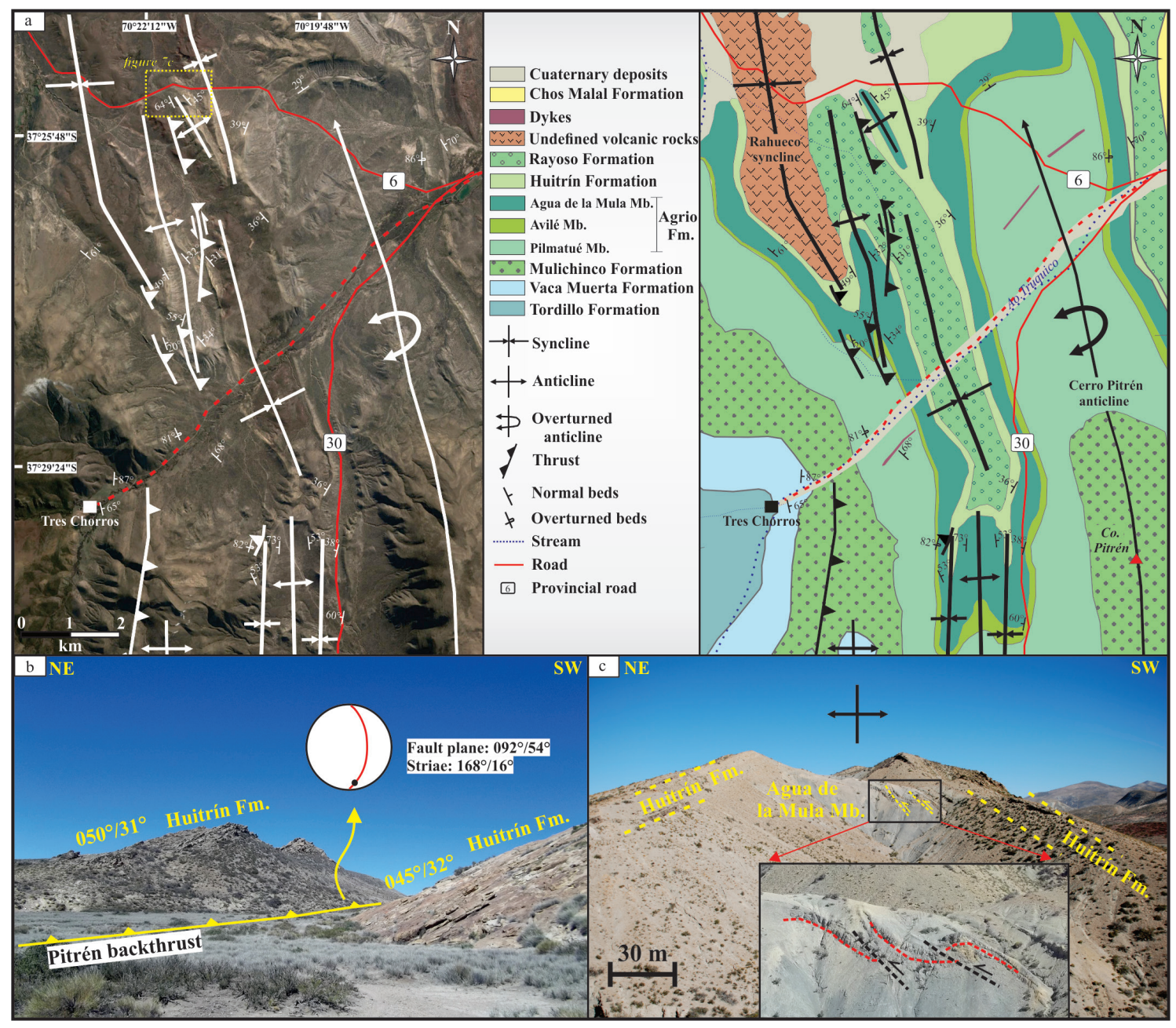

FIG. 7. a. Google Earth image and detailed geological map between Tres Chorros and Cerro Pitrén; b. Photograph of the Pitrén backthrust, a transpressive fault that duplicates the Huitrín Formation; c. Southward view of a third-order anticline, containing minor faults in the core interpreted as into-anticline thrusts.

and Rayoso formations are overturned (Fig. 8a). The backlimb of the Truquico anticline has a constant dip of $20^{\circ} \mathrm{E}$, measured in the Avilé Member along the road-cut outcrop, in a classical stop to visualise this unit in this part of the Neuquén Basin. East of the Neuquén River, the Avilé Member is tightly folded forming a NNW syncline that is cored by evaporites of the Huitrín Formation, a structure that can be well observed along the access road to Chos Malal (Figs. 3 and 8a). Based on the dimensions of the fold and the involved units, the Truquico anticline is interpreted as a third order fault-propagation fold detached above shales of the Vaca Muerta Formation (Fig. 5).
A complex structural configuration combining several NNW folds and thrusts occurs at the Loma Tilhué area, to the east of Chos Malal (Fig. 8a). Three anticlines involving the Mulichinco Formation, separated by two synclines that contain shales of the Pilmatué Member, dominate the structure of this area. These folds have wavelengths in the order of 3-4 km. The Tilhue Oeste anticline is located on the western slope of the Loma Tilhué outcrop and has a west asymmetry, as evidenced by its overturned forelimb in the Avilé Member. The Tilhué Este anticline can be observed along the Neuquén River where shales of the Vaca Muerta Formation crop out 


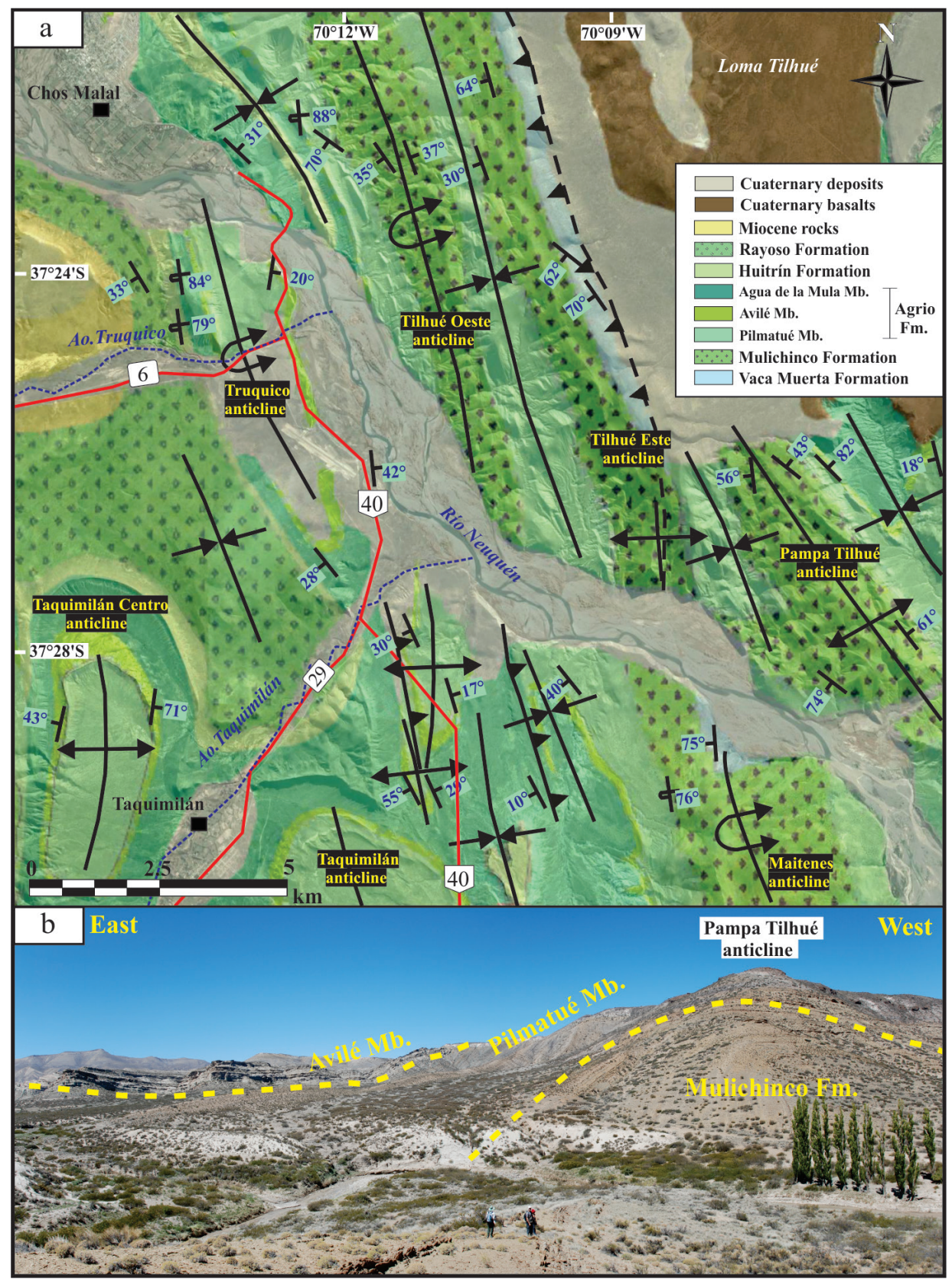

FIG. 8. a. Detailed geological map showing the structures in the Loma Tilhué area. b. Photograph of the forelimb of the Pampa Tilhué anticline and the frontal syncline cored by the Avilé Member (see location in figure 3).

in its core. In the central area of the hill, this fold is cut by a west-dipping thrust that juxtaposes the Vaca Muerta Formation with the Agrio Formation (Fig. 8a). Finally, the Pampa Tilhué anticline shows locally an eastward vergence, with dips varying from $43^{\circ}$ to $82^{\circ} \mathrm{NE}$ in the forelimb and $56^{\circ} \mathrm{SW}$ in the backlimb, while toward the south the fold-vergence changes (Fig. 8b). The sequence of deformation in this complex area will be analysed in the section 4 of this paper. 


\subsection{Structures of the south sector: cross-section b-b'}

The structural cross-section $b-b$ ' is parallel to seismic line 15007 , whose poor quality does not allow an accurate subsurface interpretation (Fig. 9). The most noticeable feature in this line is the shallowing of the basement toward the east, related to the Las Yeseras thrust as can be seen in seismic line 15009 . In addition, some disturbed areas affecting shallow reflectors correlate with the exposed anticlines, reconstructed as second order fault-related folds. Shortening resulting from the bed-length restoration of this cross-section is $10.9 \mathrm{~km}(17.3 \%)$, slightly less than in the north structural cross-section (Fig. 9).

The oldest rocks exposed in this region correspond to the Late Jurassic Tordillo Formation, which are folded forming the El Cholar and Manzano anticlines (Fig. 3). These folds have wavelengths between 7 and $9 \mathrm{~km}$ and they locate south of the Rahueco anticline, thus basement rocks should be involved at depth. Both anticlines have east vergence, in which their eastern limbs dips $50^{\circ}-60^{\circ} \mathrm{E}$ (Fig. 10a), and their western limbs dip of $15^{\circ}-30^{\circ} \mathrm{W}$ (Fig. 10b). The El Cholar anticline is interpreted as a thickskinned fault-propagation fold, with relatively minor displacement, and the Manzano anticline as a basement-involved fault-bend fold whose eastward movement produce thin-skinned deformation in the adjacent cover rocks (Fig. 9). Minor-scale folding affects the Tordillo Formation in the proximities of Tres Chorros (Figs. 3 and 10c), which can be considered thin-skinned structures probably

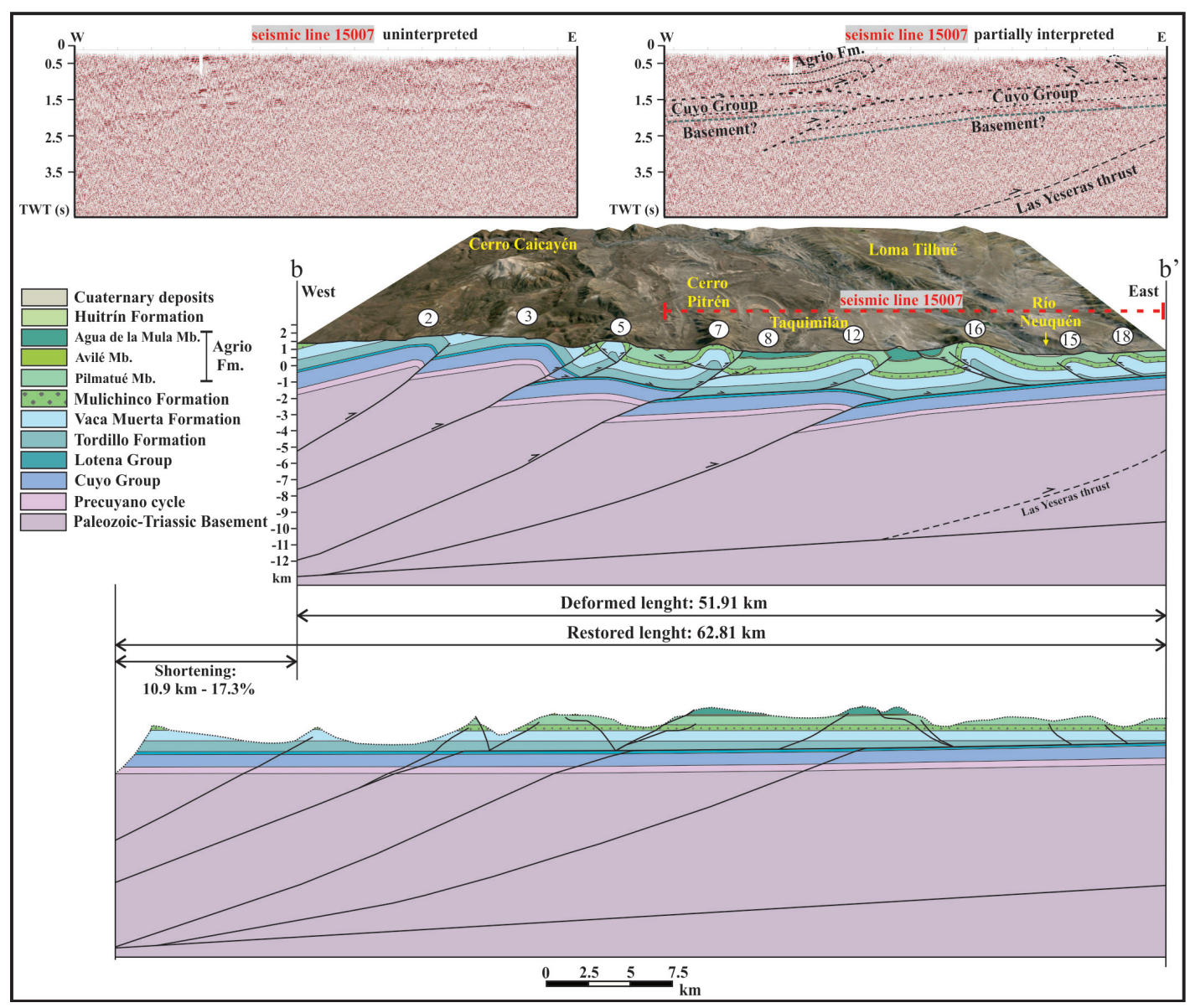

FIG. 9. Interpreted and restored structural cross-section b-b'. Because of the poor quality of seismic line 15007, it was not possible to recognize synrift geometries. As in the north cross-section (Fig. 5), large basement-involved wedges produce an intense thin-skinned deformation. 2. El Cholar anticline, 3. Manzano anticline, 5. Tres Chorros anticline, 7. Cerro Pitrén anticline, 8. Naunauco syncline, 12. Taquimilán anticline, 16. Maitenes anticline, 15. Pampa Tilhué anticline, 18. San Eduardo anticline. 


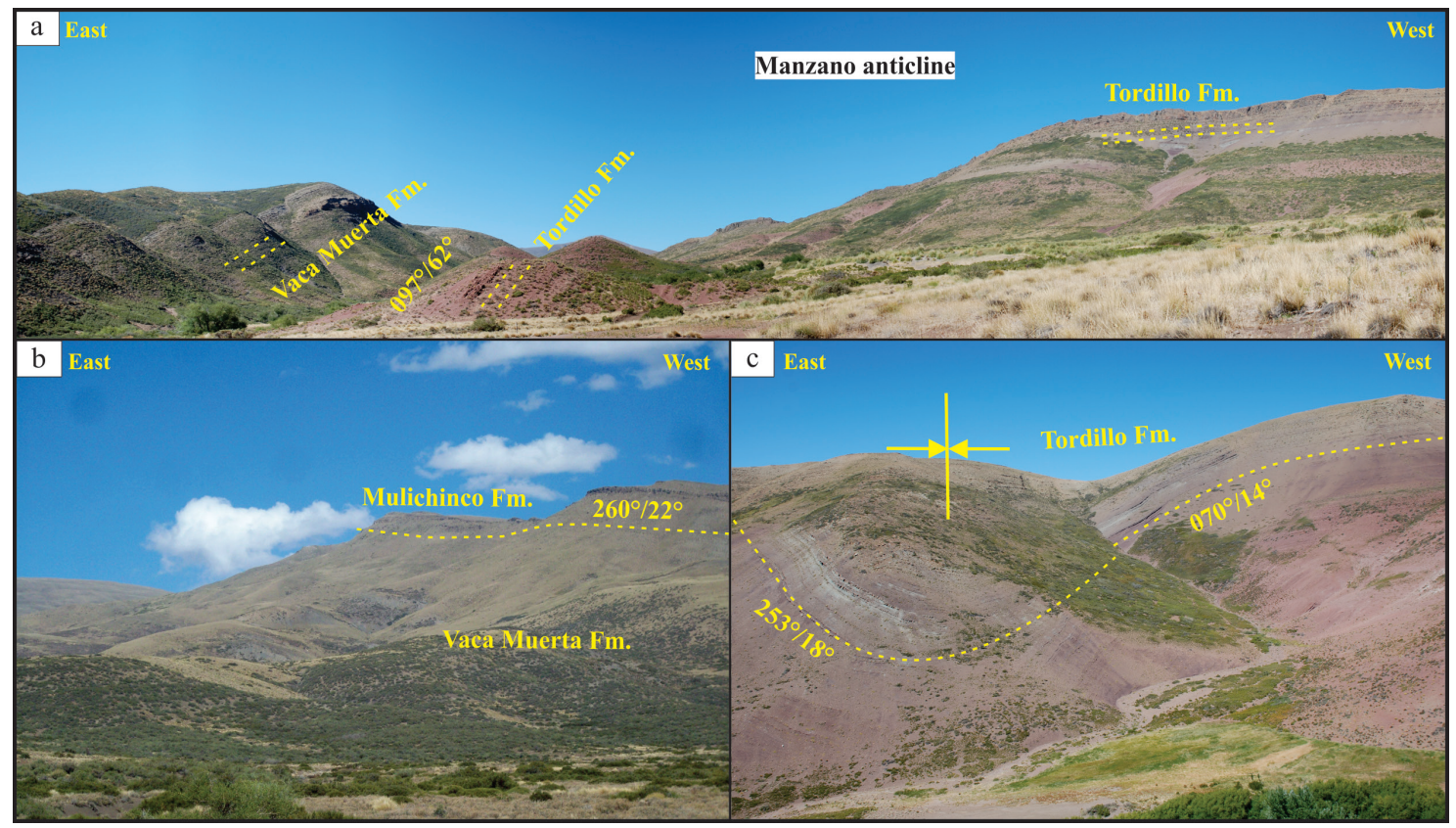

FIG. 10. a. Photograph showing the forelimb of the Manzano anticline; b. Photograph of the gently-dipping Vaca Muerta and Mulichinco formations in the backlimb of the El Cholar anticline; c. Syncline involving the Tordillo Formation near Tres Chorros (see location in figure 3).

detached from the underlying evaporites of the Auquilco Formation.

The Tres Chorros anticline is a tight, doublyvergent, N-S fold, cored by the Vaca Muerta Formation (Fig. 3). The eastern limb of this anticline is steeplydipping, and locally beds become overturned defining a dominant eastward movement. At the western limb, the Mulichinco Formation is partially thrusted over the Agrio Formation along the Tres Chorros backthrust (Fig. 3). Thus, the Tres Chorros anticline represents a pop-up structure bounded by two opposite-dipping thrusts (Fig. 9).

In cross-section a-a', the Cerro Pitrén anticline is considered a second order east-vergent fold with subordinate backthrusting in its backlimb, involving the Mendoza Group (Fig. 9). Between the Tres Chorros and Cerro Pitrén anticlines, there are smaller folds that affect the Agrio, Huitrín and Rayoso formations (Fig. 7). In this zone, there are two synclines and a tight west-vergent anticline whose backlimb and forelimb dip $52^{\circ} \mathrm{E}$ and $73^{\circ} \mathrm{W}$ respectively. These structures have been interpreted as third order folds with a detachment level in the Pilmatué Member (Fig. 9).
The subvolcanic rocks of the Naunauco Group crop out in the core of the Naunauco syncline, a broad fold developed to the southwest of Taquimilán (Fig. 3). The east-vergent Taquimilán anticline is well exposed with a wavelength of approximately $6 \mathrm{~km}$, although with low relief, between the Cerro Naunauco and the Route 40 . The western limb dip of this anticline is $23^{\circ}-41^{\circ} \mathrm{W}$ while the eastern limb dip is $68^{\circ}-72^{\circ} \mathrm{E}$ (Fig 11a). The whole Agrio Formation is involved in the Taquimilán anticline, but in some creeks near the route the Mulichinco Formation is exposed (Fig. 11b). This anticline corresponds to a second order structure interpreted as a fault-propagation fold with a detachment level in the Auquilco Formation (Fig. 9).

The west-vergent Maitenes anticline forms a prominent hill located east of route 40 , with intensely deformed shales of the Vaca Muerta Formation in its core and the Mulichinco Formation in its flanks (Figs. 11a and 12a). The backlimb dip of this anticline is $20^{\circ}-30^{\circ} \mathrm{E}$ and the forelimb dip is $70^{\circ}-75^{\circ} \mathrm{W}-\mathrm{SW}$, although locally it becomes overturned. West of the Maitenes anticline, a tight syncline involving the Agrio Formation was identified (Figs. 11a and 12b). In the western flank of this syncline, the Maitenes backthrust 


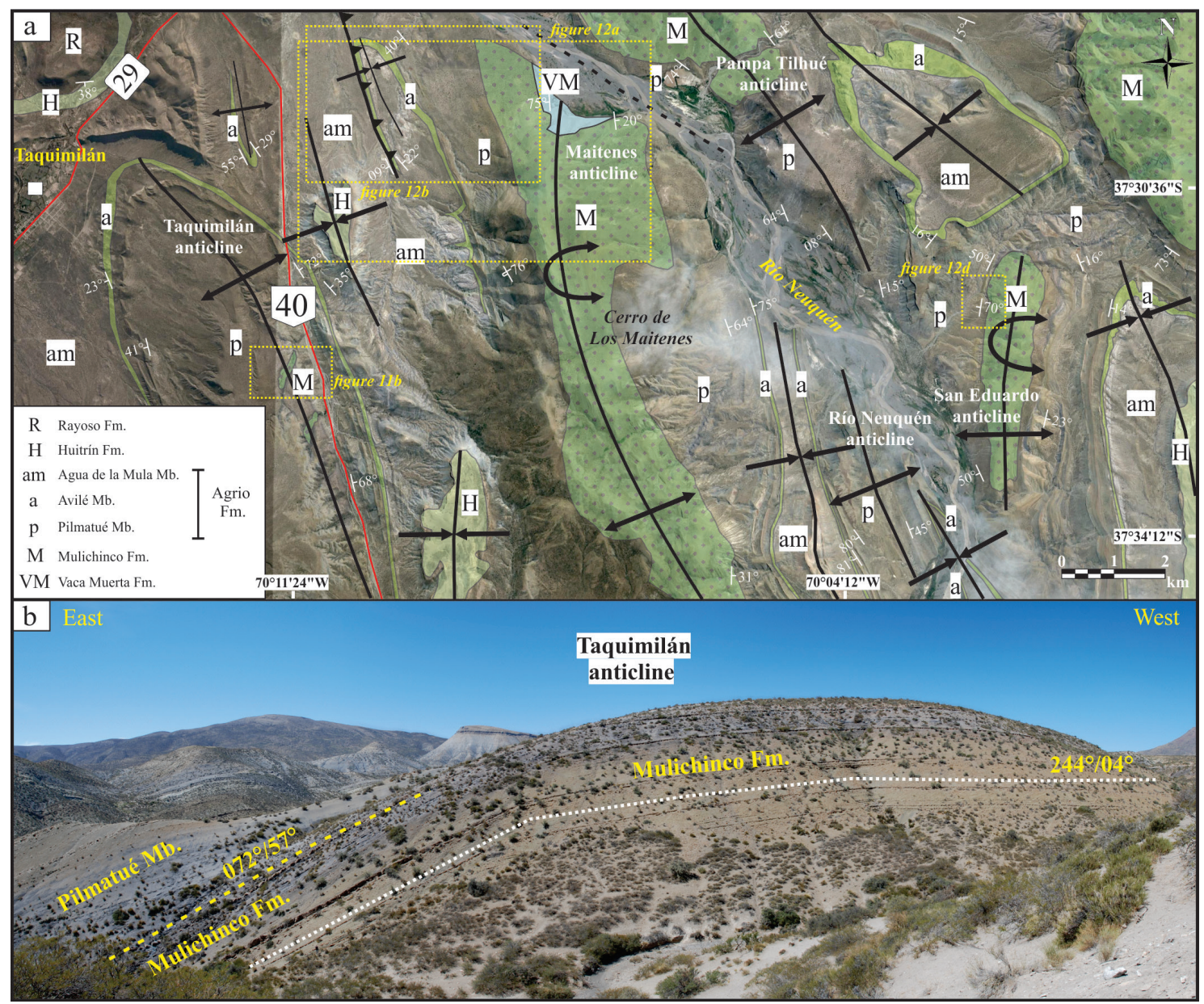

FIG. 11.a. Detailed map of the structures between Taquimilán and Cerro Curacó (see location in figure 3); b. Southward view of the Taquimilán anticline.

juxtaposes east dipping beds of the Avilé Member with top of subhorizontal layers of the Agua de la Mula Member (Fig. 12c). The average orientation of the fault plane is $049^{\circ} / 42^{\circ}$ (dip direction/dip), with striae pitching $72^{\circ} \mathrm{N}$. The Maitenes anticline has been interpreted as the result of two deformation phases, in which the first one corresponds to a fault-bend fold with an upper decollement on the Agua de la Mula Member, whose westward movement produced the Maitenes backthrust (Fig. 9). Subsequently, a breakthrough fault cut the forelimb increasing its dip and the structural relief of the fold.

The west-vergent San Eduardo anticline locates to the east of the Neuquén River, exposing the Mulichinco Formation, and it has a wavelength of approximately $5 \mathrm{~km}$ (Fig. 11a). This N-S anticline has a gently-dipping backlimb $\left(16^{\circ}-23^{\circ} \mathrm{E}\right)$ and a steeply-dipping $\left(50^{\circ}-70^{\circ} \mathrm{W}\right)$ forelimb (Figs. 9 and 12d). The Río Neuquén anticline lay between the Maitenes and San Eduardo second-order anticlines, few km to the south of the cross-section b-b' (Figs. 3 and 11a). This fold also has a west vergence, however given its smaller wavelength and the Agrio Formation involvement in the deformation it can be considered as a third order anticline.

\section{Kinematic evolution of complex thin-skinned structures}

Along the northern segment of the Agrio FTB there are complex thin-skinned structures. The Jurassic evaporites of the Auquilco Formation constitute the 


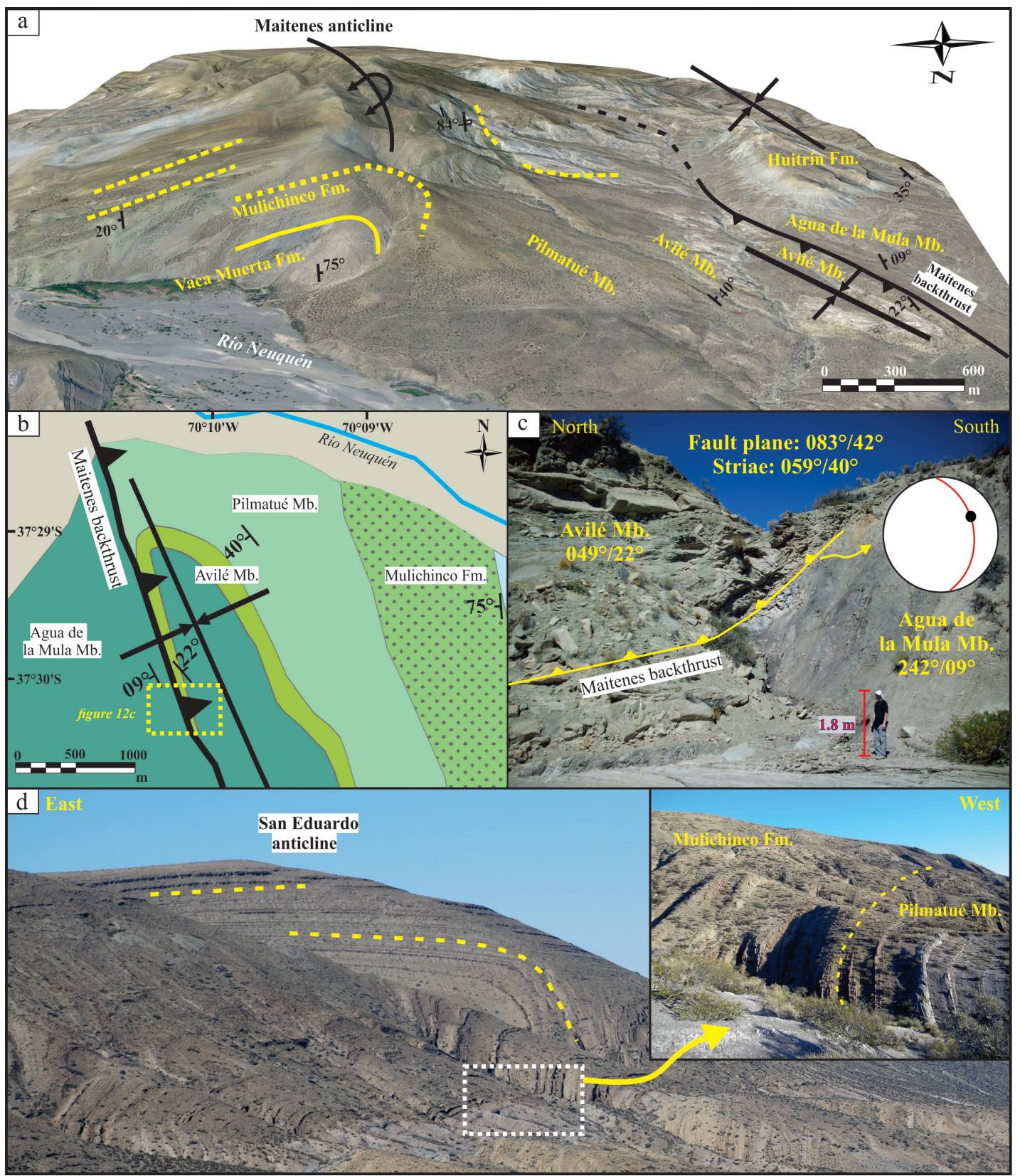

FIG. 12. a. Schematic interpretation of the Maitenes anticline over a 3D Google Earth image; b. Detailed map of third-order structures affecting the Agrio Formation to the west of the Cerro de Los Maitenes; c. Photography of the Maitenes backthrust showing the measurements on the fault plane; d. Photos of the forelimb of the west-vergent San Eduardo anticline.

main detachment into the sedimentary sequence, which allows to explain the thin-skinned folds involving the Tordillo Formation in the area of Tres Chorros (Figs. 3 and 10c). Structural studies in surrounding areas highlight the importance of these evaporitic rocks for the tectonic development of the fold and thrust belts (Zapata et al., 1999; Zapata and Folguera, 2005; Zamora Valcarce et al., 2006; Sánchez et al., 2014, 2015; Turienzo et al., 2014, 2018). Secondary detachments located in the Vaca Muerta, Agrio and 
Huitrín formations favour the formation of several orders of fault-related folds.

In our study region, an example of complex thin-skinned deformation occurs at the Loma Tilhué, where three second-order anticlines are exposed in a relatively small area (Figs. 3 and 8a). The observed structural configuration results from the combination of fault propagation folds with variable vergence that involve the entire Mendoza Group (Fig. 5).

To analyse the kinematic evolution of these structures, we built a forward model using the Fault-Fold-Forward software (Allmendinger, 2012). This program allows to reconstruct the structures as trishear fault-propagation folds and to calculate the shortening at each deformation stage. This type of fault-related fold depends on two variables: the apical angle of the trishear zone and the propagation-to-slip ratio $(\mathrm{p} / \mathrm{s})$. In trishear zones with small apical angles, intense strain is concentrated in a narrow wedge of rock, whereas broader angles result in more diffuse, less intense strain (Allmendinger, 1998). On the other hand, the $\mathrm{p} / \mathrm{s}$ ratio determines how rapidly the tip line propagates relative to the slip on the fault itself (Allmendinger, 1998). Low values of $\mathrm{p} / \mathrm{s}$ result in pronounced forelimb thickening and tight folding in the trishear zone, whereas $\mathrm{p} / \mathrm{s}>1$ results in less thickening and more open folding (Hardy and Ford, 1997). After testing with different values for these parameters, we found that the geometry and kinematics of the folds in Loma Tilhué can be adequately explained using a trishear apical angle of $60^{\circ}$ and a $\mathrm{p} / \mathrm{s}$ ratio of 2 . Before starting the model, we scaled the stratigraphical thickness of the sedimentary units involved in the deformation (Fig. 13a, pre-contractional stage).

The beginning of the thin-skinned deformation in this area is temporarily related to the insertion of basement-involved wedges onto the Auquilco Formation in the western area (Fig. 5). Displacement transferred to the east by these thick-skinned structures creates two oppositedipping thrusts in the sedimentary cover that form the Tilhué Oeste and Tilhué Este anticlines (Fig. 13a, contractional stage 1). Unfortunately, there is no evidence for distinguishing which of these folds formed first, or whether they formed simultaneously, however their combination constitutes a pop-up structure. As deformation progresses, a breakthrough fault can develop along the fold when the fault tip encounters layers that are unable to form a tighter anticline (Suppe and Medwedeff 1990). In our model, the breakthrough thrust is along the axial surface of the Tilhué Este anticline, which moved passively the Tilhué Oeste anticline and brings to the surface the shales of the Vaca Muerta Formation (Fig. 13a, contractional stage 2). Finally, a new west-dipping thrust developed in normal sequence toward the foreland forms the Pampa Tilhué anticline, folding the previous structures (Fig. 13a, contractional stage 3). The subsequent formation of the basement-involved Las Yeseras thrust in depth, generated gentle westward tilting of the thin-skinned structures. Thus, the final geometry of the modelled structures is comparable with the exposed structures in the Loma Tilhué along the cross-section a-a' (Fig. 13b).

\section{Discussion}

\subsection{Structural models and variation of tectonic shortenings}

Two main modes of deformation were commonly used in this region in order to explain the Andean mountain building: (i) positive inversion of previous normal faults (Vergani et al., 1995; Booth and Coward, 1996; Ramos, 1998; Zapata et al., 1999; Zapata and Folguera, 2005; Zamora Valcarce, 2007; Rojas Vera et al., 2015) and (ii) generation of new thrust systems (Minniti et al., 1986; Nocioni, 1996; Kozlowski et al., 1998; Turienzo et al., 2014, 2018; Sánchez et al., 2015). Despite both mechanisms probably coexisted during the Andean deformation, their relative importance and their contribution to the observed contraction along the fold and thrust belts is still a matter of debate (i.e., Mescua and Giambiagi, 2012; Dimieri and Turienzo, 2012; Turienzo et al., 2018).

Interpretation of poor-quality seismic lines in the study area does not show clear evidence of a significant inversion processes. Comparable conclusions arise from subsurface interpretations (Sánchez et al., 2015; Turienzo et al., 2018) and field observations (Sagripanti et al., 2014) in the Chos Malal FTB, where the Late Triassic-Early Jurassic normal faults were only partially inverted and they preserve their extensional character. Many regional cross-sections have been made along the Agrio and Chos Malal fold and thrust belts in the last three decades, analysing the structural style of the 


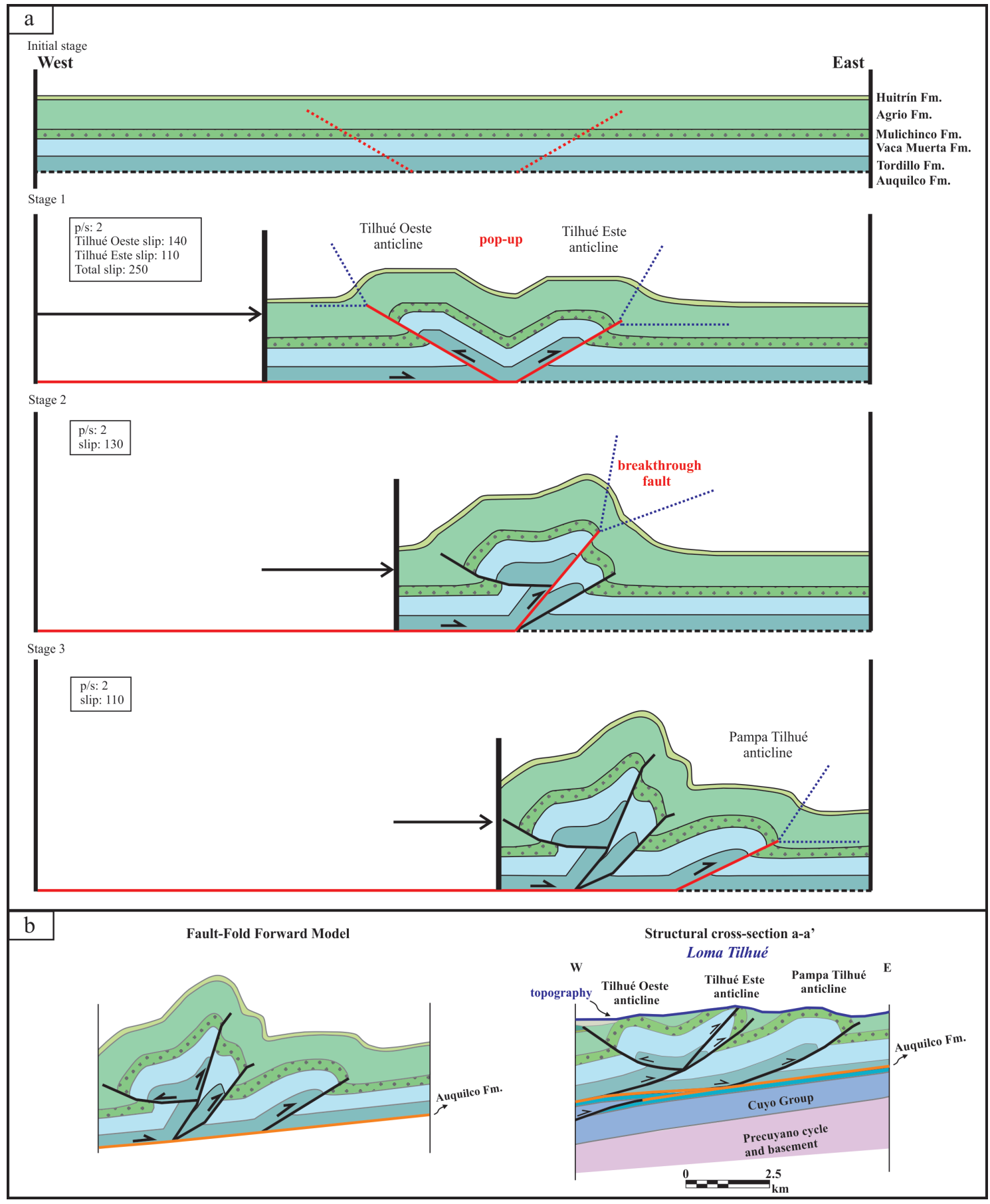

FIG. 13. a. Forward modelling constructed with the Fault Fold Forward software (Allmendinger, 2012) for explaining the sequential evolution of the complex structures at the Loma Tilhué, in cross-section a-a'. Initial Stage: Configuration of the Mesozoic units prior to the deformation; Stage 1: Development of two opposite-vergence fault-propagation anticlines creating a pop-up structure; Stage 2: Continued contraction forms an out of sequence breakthrough fault that cuts the Tilhué Este anticline; Stage 3: Formation in sequence of the Pampa Tilhué anticline, folding the previous structures to their final configuration; b. Comparison between the fault-fold forward model and the natural structures along this sector of the structural cross-section a-a'. 
deformed regions of the Neuquén Basin (Fig. 14). Most of the interpretations coincide in that the tectonic shortenings in the Andes of Neuquén decrease toward the south, from the Cordillera del Viento $\left(\sim 37^{\circ} \mathrm{S}\right)$ to the Cerro Mocho $\left(\sim 38^{\circ} \mathrm{S}\right)$. In addition, the calculated magnitudes of contraction are smaller in cross-sections considering the reactivation of normal faults as the main mechanism for the fold and thrust belt construction (Table 1).

The north to south decrease in shortening in the Chos Malal FTB coincides with the southward plunging of the Cordillera del Viento, which suggests this major thick-skinned structure strongly controls the deformation along the FTB (Sánchez et al., 2015). In the northern Agrio FTB, the thick-skinned structures at the western sector also plunges to the south, as revealed by the progressive younging of the rock sequence exposed along the Rahueco anticline (Fig. 3). Calculated shortenings show a small variation from $11.2 \mathrm{~km}(18 \%)$ in cross section a-a' to $10.9 \mathrm{~km}$ (17.3\%) in cross-section b-b' (Fig. 14). These values are comparable with the $18 \%$ contraction estimated by Minniti et al. (1986) and they are slightly higher than the $9.3 \mathrm{~km}(14 \%)$ calculated by Zamora Valcarce (2007) in the Cerro Naunauco area. Bigger discrepancies exist with the shortenings derived from the regional cross-sections of Nocioni (1996), where $43 \mathrm{~km} \mathrm{(34 \% )}$ of contraction were obtained considering the stacking of many basement-involved sheets and very low angle thrusts. On the other hand, Rojas Vera et al. (2015) interpreted along the Cerro Naunauco a regional cross-section dominated by

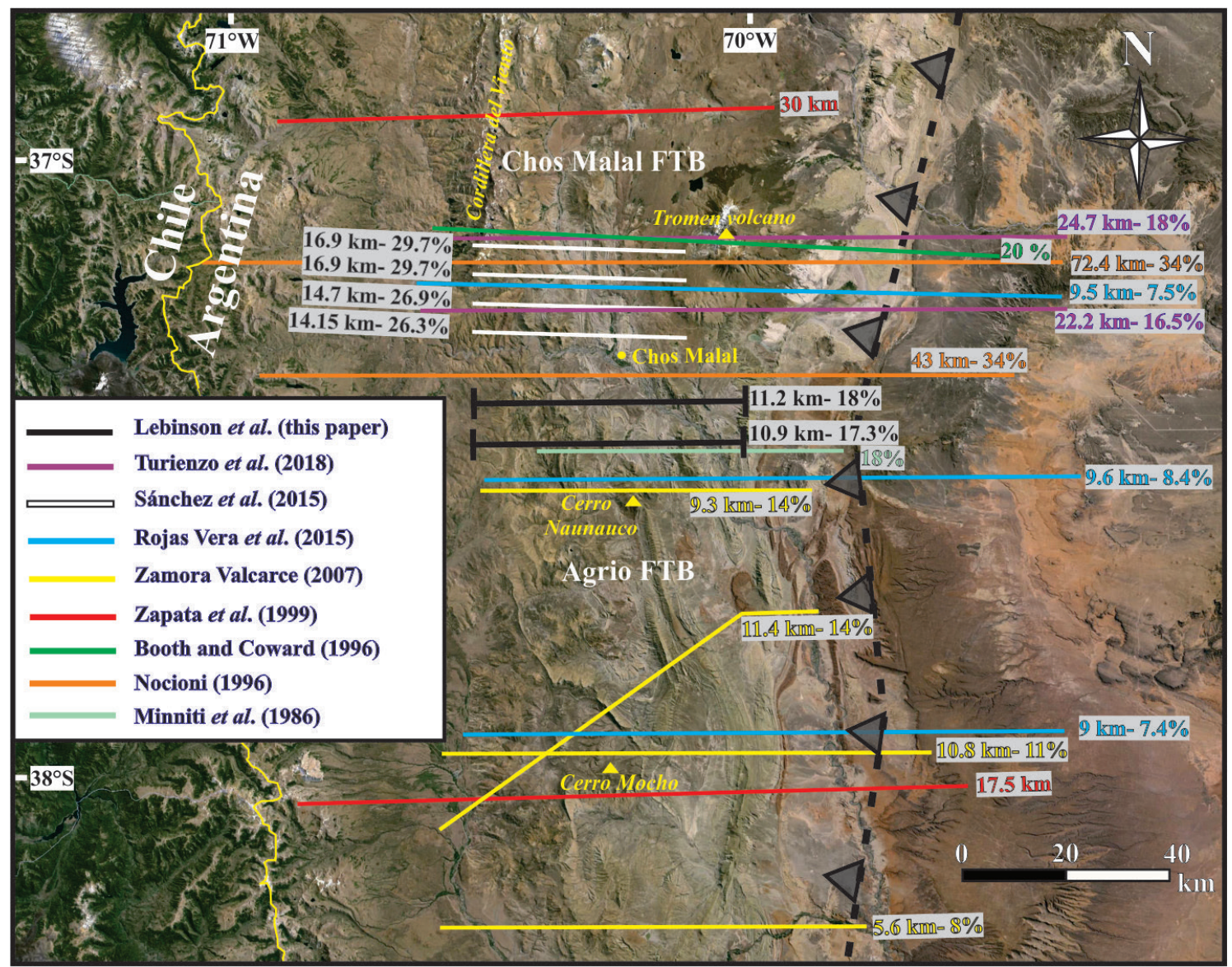

FIG. 14. Location of previous structural cross-sections along the Chos Malal and Agrio FTB showing their respective shortenings (from Minniti et al., 1986; Nocioni, 1996; Booth and Coward, 1996; Zapata et al., 1999; Zamora Valcarce, 2007; Sánchez et al., 2015; Rojas Vera et al., 2015 and Turienzo et al., 2018). The differences in the shortenings respond to latitudinal variations and the assumed structural model (see text (section 5 and table 1) for detailed explanations). 
TABLE 1. COMPARISON OF TECTONIC SHORTENING (\%) AT DISTINCT LATITUDES AND FOR DIFFERENT STRUCTURAL MODELS.

\begin{tabular}{|c|c|c|}
\hline \multirow{2}{*}{ Latitude (from North to South) } & \multicolumn{2}{|c|}{ Shortening (\%) by tectonic model } \\
\hline & Andean thrusts system & Inversion normal faults \\
\hline Cordillera del Viento $\left(37^{\circ} 10^{\prime} \mathrm{S}\right)$ & $\begin{array}{c}\text { 26.3-29.7 (Sánchez et al., 2015) } \\
\text { 16.5-18 (Turienzo et al., (2018) } \\
34 \text { (Nocioni, 1996) }\end{array}$ & $\begin{array}{c}7.5 \text { (Rojas Vera et al., 2015) } \\
20 \text { (Booth and Coward, 1996) }\end{array}$ \\
\hline Cerro Caicayén (37²7’’S) & $\begin{array}{c}18 \text { (Lebinson et al., this paper) } \\
34 \text { (Nocioni, 1996) }\end{array}$ & - \\
\hline Cerro Naunauco (37³3’S) & $\begin{array}{c}17.3 \text { (Lebinson et al., this paper) } \\
18 \text { (Minniti et al., 1986) }\end{array}$ & $\begin{array}{l}8.4 \text { (Rojas Vera et al., 2015) } \\
14 \text { (Zamora Valcarce, 2007) }\end{array}$ \\
\hline Cerro Mocho $\left(38^{\circ} \mathrm{S}\right)$ & - & $\begin{array}{c}\text { 7.4 (Rojas Vera et al., 2015) } \\
\text { 8-14 (Zamora Valcarce, 2007) }\end{array}$ \\
\hline
\end{tabular}

inverted normal faults, calculating a shortening of only $9.6 \mathrm{~km}(8.4 \%)$. It should be noted that since the sections interpreted by the different authors do not have the same lengths, the percentage shortening should be compared in order to analyse variations in contraction.

In the studied segment of the Agrio FTB our estimated shortenings result dominantly from the restoration of the sedimentary cover, which contains six thin-skinned fault-related folds constrained by field data (Figs. 5 and 9). The lack of evidence of relevant inversion tectonics, together with the mechanical difficulty of high-angle normal faults to accommodate considerable contractions, led us to consider an alternative interpretation. We propose a regional structural model in which major basementinvolved thrusts form first order wedges and transfer displacement to the cover, producing second order fault-related folds. Moreover, some second order structures are interpreted as fault-bend anticlines with an upper decollement in shallow stratigraphic levels, whose displacement produces minor-scale structures (third and fourth order).

\subsection{Age of deformation and structural evolution}

The analysis of the structures in the study area, in conjunction with the existing ages of the igneous rocks exposed in the region, allows the reconstruction of a possible sequence of deformation for the northernmost segment of the Agrio FTB (Fig. 15).

In the region of Cerro Mocho, approximately $75 \mathrm{~km}$ to the south of Chos Malal city, there are several E-W basaltic dykes with ${ }^{40} \mathrm{Ar} /{ }^{39} \mathrm{Ar}$ ages of 101.9 $\pm 0.69 \mathrm{Ma}$ and $91.97 \pm 4.06 \mathrm{Ma}$ that cross-cut the folds, suggesting a Cretaceous E-W compressive event prior to $\sim 100 \mathrm{Ma}$ (Zamora Valcarce et al., $2006,2009)$. These values are unique in the whole region and it should not be ruled out that a possible enrichment of argon has resulted in older ages (Llambías et al., 2011).

Cobbold and Rossello (2003) observed in outcrops and in seismic lines an angular unconformity between the Huitrín and Rayoso formations, approximately $25 \mathrm{~km}$ to the southeast of the study area. Thus, they proposed the beginning of Andean compression during the upper Early Cretaceous (Aptian-Albian). Other studies consider that the red beds of the Neuquén Group, which lie unconformably over the Rayoso Formation, are synorogenic deposits accumulated in a foreland basin related to Late Cretaceous deformation (Ramos, 1981; Ramos and Folguera, 2005; Zamora Valcarce et al., 2009; Tunik et al., 2010). In addition, Cobbold and Rossello (2003) argued that folding was active from the Late Cretaceous and continued until the Eocene based on the angular unconformity between Cayanta Formation $\left(39 \pm 9.1 \mathrm{Ma}{ }^{40} \mathrm{~K} /{ }^{40} \mathrm{Ar}\right.$, Llambías and Rapela, 1989) and the Bajada del Agrio Group in the Colipilli region. Through the study of apatite fission tracks, Rojas Vera et al. (2015) proposed that the Cretaceous deformation extends to the Paleocene, and perhaps until the Eocene. Our kinematic model, based on the cross-section a-a', indicates that the initial deformation occurred during the Late Cretaceous-Eocene stage with the formation of the Rahueco basement-involved wedge 


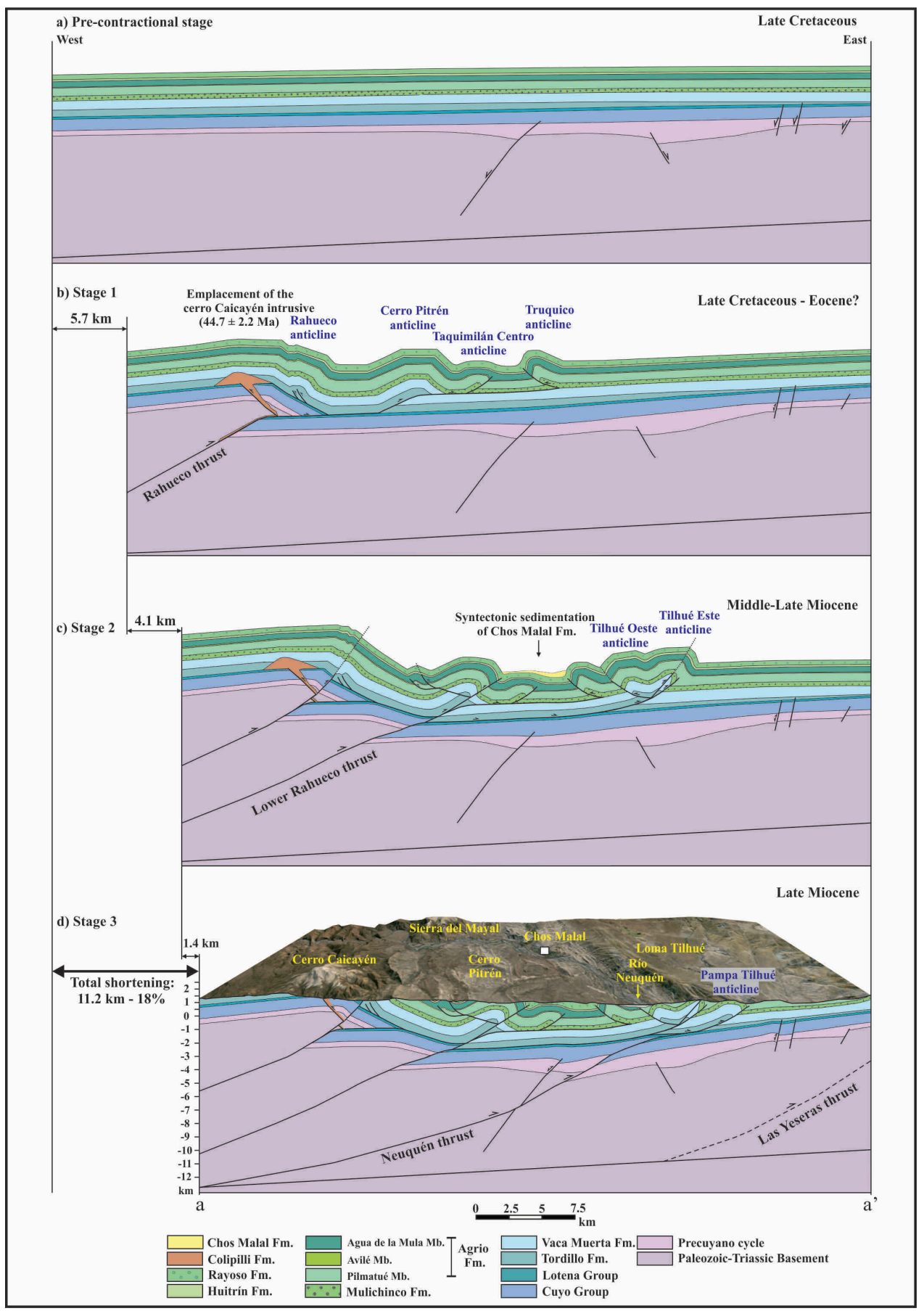

FIG. 15. Proposed kinematic evolution of the tectonic structures along a-a' structural cross-section. a. Stage prior to the Andean contraction (before the Late Cretaceous); b. The Rahueco anticline, formed during the Late Cretaceous-Eocene compressive phase that is related to a basement-involved thrust that moves eastward along the Auquilco Formation generating the thinskinned Cerro Pitrén, Taquimilán Centro and Truquico anticlines; c. The Lower Rahueco basement-involved thrust generates the structures at Loma Tilhué during the Middle-Late Miocene, simultaneously with synorogenic sedimentation of the Chos Malal Formation; d. Generation of the thick-skinned Neuquén thrust that partially cuts an inverted normal fault forming the Pampa Tilhué anticline. Generalized rotation of the easternmost structures occurs over the hangingwall of the Las Yeseras thrust, probably in the Late Miocene. 
(Fig. 15 stage 1). As this first-order structure moves eastward along the evaporites of the Auquilco Formation it generates the Cerro Pitrén anticline (second-order structure), which in turn transmits deformation to shallower levels forming third-order structures as the Taquimilán Centro and Truquico anticlines. A deformation model that links thickskinned structures with thin-skinned fault-related folds of different order was proposed and documented in the Chos Malal FTB (Kozlowski et al., 1998; Sánchez et al., 2014, 2015; Turienzo et al., 2014, 2018). The Eocene igneous rocks that form the Cerro Caicayén intrude Jurassic strata using the backthrusts in the forelimb of the Rahueco anticline as feed channels, suggesting that the deformation of the area predated intrusion or were contemporaneous (Lebinson et al., 2015b).

Synorogenic accumulation of the Puesto Burgos, Rincón Bayo and Chos Malal formations (Cervera and Leanza, 2009), together with the Tralalhué Conglomerate (Ramos, 1998), evidence a MiddleLate Miocene contractional event in the Agrio FTB. Zamora Valcarce et al. (2009) correlate the deposits of Puesto Burgos and Rincón Bayo formations with two deformation events, at $11 \mathrm{Ma}$ and $6 \mathrm{Ma}$, interpreted from apatite fission track analysis in the Dorso de los Chihuidos. From the sequential reconstruction, a second basement involved thrust formed during the Middle-Late Miocene compression, in which both reactivated previous structures and created the faultrelated folds in the Loma Tilhué (Fig. 15 stage 2). Sedimentation of the Chos Malal Formation at this stage took place in a small piggy back basin restricted to the Truquico syncline (Cervera and Leanza, 2009). Folding and meter scale structures within this unit evidence that deformation continued after its sedimentation. As deformation progressed, a third basement-involved thrust cut a partially inverted normal fault, transmitting displacement to the cover and the consequent creation of the Pampa Tilhué anticline (Fig. 15 stage 3). Finally, the basement-involved Las Yeseras thrust forms toward the foreland, out of the study area, creating the regional slope observed in the easternmost portion of the cross-sections and in the seismic lines.

\section{Conclusions}

Based on detailed field mapping and of 2D seismic sections interpretation we constructed two balanced cross-sections that allow the characterization of the structural style of the northern Agrio FTB. The structures recognized in this region include first-order basement-involved anticlines, with large fold wavelengths, and second-order thin-skinned anticlines with shorter wavelengths. Moreover, minor-scale structures (third and fourth order), that involve successively shallower stratigraphic units were recognised. Forward modelling of secondorder folds allows to understand the kinematics of complex thin-skinned structures as the Loma Tilhué anticlines that formed by the combination of a popup and imbricate thrust-related-folds. Because of the poor quality of the seismic data, it was difficult to recognize the precise geometry of the structures in depth. However, in the northernmost seismic section, synrift geometries related with normal faults with slight positive inversion were inferred. The restoration of the structural cross-sections shows tectonic shortenings ranging from $11.2 \mathrm{~km}(18 \%)$ to $10.9 \mathrm{~km}(17.3 \%)$, suggesting a slight southward decrease of contraction, consistent with previous interpretations along the Neuquén Andes.

A structural model that explains the development of the northern Agrio FTB is proposed. This model considers a close temporal and spatial relationship between the thick and the thin skinned structures developed during the Andean orogeny. Throughout the study area, major thrusts produce first order basement-involved wedges that move forward on a decollement surface in the Late Jurassic evaporites of the Auquilco Formation. These transferred displacements give rise to second order faultpropagation and fault-bend folds in the overlying rocks. The proposed structural analysis suggests a model of thick-skinned deformation, characterized by newly developed Andean thrust systems as the main mechanism producing contraction in this fold and thrust belt. By means of an integration of the studied structures with the existing geochronological data, a kinematic evolution that explains the structural development of the northern Agrio FTB in two main compressive phases (Late Cretaceous-Eocene and the Middle-Late Miocene) is proposed.

\section{Acknowledgments}

This work was financed by CONICET PIP 0583, CONICET P-UE47CO, FONCYT PICT 2015-0419 y SECYTUNS PGI 24/h136. We are grateful to the Departmento de Geología of the Universidad Nacional 
del Sur and INGEOSUR-CONICET for logistical and financial support. We also acknowledge the Subsecretaría de Energía, Minería e Hidrocarburos of the Neuquén Province for providing the seismic lines and well information, and the Municipalidad of Chos Malal for supporting the field work. We greatly appreciate the comments and suggestions by reviewer J. Skármeta and Editor W. Vivallo, which considerably improved this paper.

\section{References}

Allmendinger, R.W. 1998. Inverse and forward numerical modeling of trishear faultpropagation folds. Tectonics 17 (4): 640-656.

Arregui, C.; Carbone, O.; Leanza, H.A. 2011. Contexto tectonosedimentario. In Relatorio Geología y Recursos Naturales de la provincia del Neuquén (Leanza, H.A.; Arregui, C.; Carbone, O.; Danieli, J.C.; Vallés, J.M.; editores). Asociación Geológica Argentina: 29-36. Neuquén.

Bracaccini, I.O. 1970. Rasgos tectónicos de las acumulaciones mesozoicas en las provincias de Mendoza y Neuquén, República Argentina. Revista de la Asociación Geológica Argentina 25 (2): 275-282. Buenos Aires.

Booth, J.; Coward, M. 1996. Basement faulting and inversión of the NW Neuquén Basin, Argentina. In International Symposium on Andean Geodynamics, No. 3, Extended Abstracts: 295-298. St. Malo.

Carbone, O.; Franzese, J.; Limeres, M.; Delpino, D.; Martínez, R. 2011. EL Ciclo Precuyano (Triásico Tardío-Jurásico Temprano) en la Cuenca Neuquina. In Relatorio Geología y Recursos Naturales de la provincia del Neuquén (Leanza, H.A.; Arregui, C.; Carbone, O.; Danieli, J.C.; Vallés, J.M.; editors). Asociación Geológica Argentina: 63-76. Neuquén.

Cervera, M.; Leanza, H.A. 2009. Hallazgo de sedimentitas sinorogénicas neógenas en los alrededores de Chos Malal, Cuenca Neuquina, Argentina. Revista del Museo Argentino de Ciencias Naturales 11 (1): 1522. Buenos Aires.

Cobbold, P.; Rossello, E. 2003. Aptian to recent compressional deformation, foothills of the Neuquén Basin Argentina. Marine and Petroleum Geology 20: 429-443.

Dahlstrom, C.D.A. 1969. Balanced cross sections: Canadian Journal of Earth Sciences 6: 743-757.

Danieli, J.C.; Coppolecchia, M.; Elisondo, M. 2011. El Grupo Andacollo (Paleozoico Tardío). In Relatorio Geología y Recursos Naturales de la provincia del Neuquén (Leanza, H.A.; Arregui, C.; Carbone, O.;
Danieli, J.C.; Vallés, J.M.; editors). Asociación Geológica Argentina: 49-62. Buenos Aires.

Digregorio, J.H.; Uliana, M. 1980. Cuenca Neuquina. In Simposio de Geología Regional Argentina, No. 2 (Turner, J.C.; editors): 985-1032. Córdoba.

Dimieri, L.; Turienzo, M. 2012. Comment on: "Fault inversion vs. new thrust generation: A case study in the Malargüe fold-and-thrust belt, Andes of Argentina" by J. F. Mescua and L. B. Giambiagi. Journal of Structural Geology 42: 279-282.

Dyhr, C.T.; Holm, P.M.; Llambías, E.J.; Scherstén, A. 2013. Subduction controls on Miocene back-arc lavas from Sierra de Huantraico and La Matancilla, Argentina and new ${ }^{40} \mathrm{Ar} /{ }^{39} \mathrm{Ar}$ dating from the Mendoza Region, Argentina. Lithos 179: 67-83.

Franzese, J.R.; Spalletti, L.A. 2001. Late Triassic-early Jurassic continental extension in southwestern Gondwana: tectonic segmentation and pre-break-up rifting. Journal of South American Earth Sciences 14: 257-270.

Groeber, P. 1929. Líneas fundamentales de la geología del Neuquén, sur de Mendoza y regiones adyacentes. Dirección Nacional de Geología y Minería, Publicación 58: 1-109. Buenos Aires.

Groeber, P. 1946. Observaciones geológicas a lo largo del meridiano 70. Hoja Chos Malal. Revista de la Asociación Geológica Argentina 1: 178-208. Buenos Aires.

Gulisano, C.; Gutiérrez Pleimling, A. 1995. The Jurassic of the Neuquén Basin, a) Neuquén Province. Secretaría de Minería de la Nación, Publicación 158: 111 p.

Hardy, S.; Ford, M. 1997. Numerical modeling of trishear fault-propagation folding and associated growths trata. Tectonics 1 (6): 841-854.

Kay, S.M.; Burns, M.; Copeland, P. 2006. Upper Cretaceous to Holocene magmatism and evidence for transient Miocene shallowing of the Andean subduction zone under the northern Neuquén Basin. In Evolution of an Andean Margin: A tectonic and magmatic view from the Andes to the Neuquén Basin (35-39 S) (Kay, S.M.; Ramos, V.A.; editors). Geological Society of America, Special Paper 407: 19-60.

Kozlowski, E.; Cruz, C.; Sylwan, C.A. 1996. Geología estructural de la zona de Chos Malal. Cuenca Neuquina, Argentina. In Congreso Geológico Argentino, No. 13 y Congreso de Exploración de Hidrocarburos, No. 3, Actas 1: 15-26. Buenos Aires.

Kozlowski, E.; Cruz, C.; Sylwan, C. 1998. Modelo exploratorio en la faja corrida de la Cuenca Neuquina, Argentina. Boletín de Informaciones Petroleras 55: 4-23. 
Leanza, H.A.; Repol, D.; Hugo, C.A.; Sruoga, P. 2006. Hoja Geológica 3769-31 Chorriaca, provincia de Neuquén. Programa Nacional de Cartas Geológicas de la República Argentina a escala 1:100.000. Instituto de Geología y Recursos Minerales, Servicio Geológico Minero Argentino, Boletín 354: 1-93. Buenos Aires.

Leanza, H.A.; Mazzini, A.; Corfu, F.; Llambías, E.J.; Svensen, H.; Planke, S.; Galland, O. 2013. The Chachil Limestone (Pliensbachian earliest Toarcian) Neuquén Basin, Argentina: U-Pb age calibration and its significance on the Early Jurassic evolution of southwestern Gondwana. Journal of South American Earth Sciences 42: 171-185.

Lebinson, F.; Turienzo, M.; Sánchez, N.; Araujo, V.; Dimieri, L. 2015a. Geometría y cinemática de las estructuras tectónicas en el extremo septentrional de la faja corrida y plegada del Agrio, Cuenca Neuquina. Revista de la Asociación Geológica Argentina 72 (3): 299-313.

Lebinson, F.; Turienzo, M.; Araujo, V.; Sánchez, N.; Dimieri, L. 2015b. Control estructural en el emplazamiento de las rocas ígneas del cerro Caicayén, faja corrida y plegada del Agrio, Neuquén. In Reunión de Tectónica, No. 16: 138-139. Río Negro.

Legarreta, L.; Gulisano, C. 1989. Análisis estratigráfico secuencial de la Cuenca Neuquina (Triásico superiorTerciario inferior). In Cuencas Sedimentarias Argentinas (Chebli, G.; Spalletti, L.; editors), Universidad Nacional de Tucumán, Serie Correlación Geológica 6: 221-243. Tucumán.

Legarreta, L.; Uliana, M.A. 1991. Jurassic-Cretaceous marine oscillations and geometry of backarc basin fill. Central Argentine Andes. In Sea level changes at active plate margins (McDonald, D.I.M.; editor). International Association of Sedimentology, Special Publication 12: 429-450.

Legarreta, L.; Uliana, M. A. 1996. The Jurassic succession in west-central Argentina: stratal patterns, sequences and paleogeographic evolution. Paleogeography, Paleoclimatology, Paleoecology 120: 303-330.

Llambías, E.J.; Rapela, C.W. 1989. Las vulcanitas de Colipilli, Neuquén, y su relación con otras unidades paleógenas de la Cordillera. Revista de la Asociación Geológica Argentina 44: 224-236. Buenos Aires.

Llambías, E.J.; Sato, A.M. 2011. Ciclo Gondwánico: la provincia magmática Choiyoi en Neuquén. In Relatorio Geología y Recursos Naturales de la provincia del Neuquén (Leanza, H.A.; Arregui, C.; Carbone, O.; Danieli, J.C.; Vallés, J.M.; editors). Asociación Geológica Argentina: 53-62. Neuquén.

Llambías, E.; Leanza, H.; Carbone, O. 2007. Evolución tectono-magmática durante el Pérmico al Jurásico Temprano en Cordillera del Viento ( $\left.37^{\circ} 5^{\prime} \mathrm{S}-37^{\circ} 15^{\prime} \mathrm{S}\right)$ : Nuevas Evidencias geológicas y geoquímicas del inicio de la Cuenca Neuquina. Revista de la Asociación Geológica Argentina 62: 217-235. Buenos Aires.

Llambías, E.; Leanza, H.; Galland, O. 2011. Agrupamiento volcánico Tromen-Tilhué. In Geología y Recursos Naturales de la Provincia de Neuquén (Leanza, H.; Arregui, C.; Carbone, O.; Danieli, J.; Vallés, J.; editors). Asociación Geológica Argentina: 627-636. Neuquén.

Mescua, J.F.; Giambiagi, L.B. 2012. Fault inversion vs. new thrust generation: a case study in the Malargüe fold-and-thrust belt, Andes of Argentina. Journal of Structural Geology 35: 51-63. Amsterdam.

Mitra, S. 2002. Fold-accommodation faults. AAPG Bulletin 86 (4): 671-693.

Nocioni, A.D. 1996. Estudio estructural de la Faja Plegada y Corrida de la Cuenca Neuquina-Surmendocina. In Congreso Geológico Argentino, No. 13 y Congreso de Exploración de Hidrocarburos, No. 3, Actas 2: 353-372. Buenos Aires.

Ramos, V.A. 1978. Estructura. In Geología y Recursos Naturales del Neuquén y Congreso Geológico Argentino, No. 7 (Yrigoyen, M.R.; editor). Relatorio: 99-118. Buenos Aires.

Ramos, V.A. 1981. Descripción geológica de la Hoja 33c, Los Chihuidos Norte. Boletín del Servicio Geológico Nacional 182 (escala 1:200.000): 103 p. Buenos Aires.

Ramos, V.A. 1998. Estructura del sector occidental de la faja plegada y corrida del Agrio, cuenca Neuquina, Argentina. In Congreso Latinoamericano de Geología, No. 10, Actas 2: 105110. Buenos Aires.

Ramos, V.A. 1999. Plate tectonic setting of the Andean cordillera. Episodes 22 (3): 183-190.

Ramos, V.A.; Barbieri, M. 1989. El volcanismo cenozoico de Huantraico: Edad y relaciones isotópicas iniciales, provincia de Neuquén. Revista de la Asociación Geológica Argentina 43: 210-223.

Ramos, V.A.; Folguera, A. 2005. Tectonic evolution of the Andes of Neuquén: Constraints derived from the magmatic arc and foreland deformation. In The Neuquén Basin: A case study in sequence stratigraphy and basin dynamics (Spalletti, L.; Veiga, G.; Schwarz, E.; Howell, J.; editors). 
Geological Society, Special Publications 252: 15-35. London.

Repol, D.; Leanza, H.A.; Sruoga, P.; Hugo, C.A. 2002. Evolución tectónica del Cenozoico de la comarca de Chorriaca, Provincia del Neuquén, Argentina. In Congreso Geológico Argentino, No. 15, Actas en CD Room. El Calafate.

Rojas Vera, E.; Mescua, J.; Folguera, A.; Becker, T.P.; Sagripanti, L.; Fenell, L.; Orts, D.; Ramos, V.A. 2015. Evolution of the Chos Malal and Agrio fold and thrust belts, Andes of Neuquén: Insights from structural analysis and apatite fission track dating, Journal of South American Earth Sciences 64: 418-433.

Sagripanti, L.; Folguera, A.; Giménez, M.; Rojas Vera, E.A.; Fabiano, J.J.; Molnar, N.; Fennell L.; Ramos, V.A. 2014. Geometry of middle to late Triassic extensional deformation pattern in the Cordillera del Viento (Southern Central Andes): a combined field and geophysical study. Journal of Iberian Geology 40: 349-366.

Sánchez, N.P.; Turienzo, M.M.; Dimieri, L.V.; Araujo, V.S.; Lebinson, F. 2014. Evolución de las estructuras andinas en la faja corrida y plegada de Chos Malal: interacción entre el basamento y la cubierta sedimentaria de la Cuenca Neuquina. Revista de la Asociación Geológica Argentina 71: 233-246. Buenos Aires.

Sánchez, N.; Turienzo, M.; Lebinson, F.; Araujo, V.; Coutand, I.; Dimieri, L. 2015. Structural style of the Chos Malal fold and thrust belt, Neuquén basin, Argentina: Relationship between thick- and thinskinned tectonics. Journal of South American Earth Sciences 64: 399-417.

Suppe, J.; Medwedeff, D. 1990. Geometry and kinematics of fault-propagation folding: Eclogae Geologicae Helvetiae 83: 409-454.

Tunik, M.; Folguera, A.; Naipauer, M.; Pimentel, M.; Ramos, V.A. 2010. Early uplift and orogenic deformation in the Neuquén basin: Constraints on the Andean uplift from $\mathrm{U}-\mathrm{Pb}$ and $\mathrm{Hf}$ isotopic data of detrital zircons. Tectonophysics 489: 258-273.

Turienzo, M.; Sánchez, N.; Dimieri, L.; Lebinson, F.; Araujo, V. 2014. Tectonic repetitions of the Early Cretaceous Agrio Formation in the Chos Malal fold-and-thrust belt, Neuquén basin, Argentina: geometry, kinematics and structural implications for Andean building. Journal of South American Earth Sciences 53: 1-19.

Turienzo, M.; Sánchez, N.; Lebinson, F.; Dimieri, L. 2018. The structure of the Southern Central Andes (Chos Malal fold and thrust belt). In The Evolution of the
Chilean-Argentinean Andes (Folguera, A.; Contreras Reyes, E.; Heredia, N.; Encinas, A.; Iannelli, S.; Oliveros, V.; Dávila, F.; Collo, G.; Giambiagi, L.; Maksymowicz, A.; Iglesia Llanos, M.P.; Turienzo, M.; Naipauer, M.; Orts, D.; Litvak, V.; Álvarez, O.; Arriagada, C.; editors). Springer Earth System Sciences: 411-441. doi: 10.1007/978-3-319-67774-3_17.

Veiga, G.D.; Spalletti, L.A.; Flint, S. 2002. Aeolian/fluvial interactions and high-resolution sequence stratigraphy of a non-marine lowstand wedge: the Avilé Member of the Agrio Formation (Lower Cretaceous), central Neuquén Basin, Argentina. Sedimentology 49: 10011019.

Vergani, G.D.; Tankard, A.J.; Belotti, H.J.; Weisink, H.J. 1995. Tectonic evolution and paleogeography of the Neuquén Basin, Argentina. In Petroleum Basins of South America, American Association of Petroleum Geologists, Memoir 62: 383-402.

Weaver, C. 1927. The Roca Formation in Argentina. American Journal of Science 13 (5): 417-434.

Zamora Valcarce, G. 2007. Estructura y cinemática de la faja plegada del Agrio. Tesis doctoral (Inédito), Universidad de Buenos Aires: 304 p. Buenos Aires.

Zamora Valcarce, G.; Zapata, T.; Delpino, D.; Ansa, A. 2006. Structural evolution and magmatic characteristics of the Agrio fold-and-thrust belt. In Evolution of an Andean margin: A tectonic and magmatic view from the Andes to the Neuquén Basin (35-39 S lat) (Kay, S.M.; Ramos, V.A.; editors). Geological Society of America, Special Paper 407: 125-145. New York.

Zamora Valcarce, G.; Zapata, T.; Ramos, V.A.; Rodríguez, F.; Bernardo, L.M. 2009. Evolución tectónica del Frente Andino en Neuquén. Revista de la Asociación Geológica Argentina 65: 192-203. Buenos Aires.

Zapata, T.; Folguera, A. 2005. Tectonic evolution of the Andean fold and thrust belt of the southern Neuquén Basin, Argentina. In The Neuquén Basin: A case study in sequence stratigraphy and basin dynamics (Veiga, G.; Spalletti, L.; Schwarz, E.; Howell, J.; editors). Geological Society, Special Publications 252: 37-56. London.

Zapata, T.; Brissón, I.; Dzelalija, F. 1999. La estructura de la faja plegada y corrida andina en relación con el control del basamento de la Cuenca Neuquina. Boletín de Informaciones Petroleras 60: 113-121. Buenos Aires.

Zapata, T.; Córsico, S.; Dzelalija, F.; Zamora Valcarce, G. 2002. La faja plegada y corrida del Agrio: Análisis 
estructural y su relación con los estratos terciarios de la Cuenca Neuquina, Argentina. In Congreso de exploración y desarrollo de Hidrocarburos, No. 5, Actas en CD Room. Mar del Plata.
Zöllner, W.; Amos, A.J. 1973. Descripción geológica de la Hoja 32b, Chos Malal, provincia del Neuquén. Servicio Geológico Minero Argentino, Boletín 143: 91 p. Buenos Aires.

Manuscript received: March 16, 2017; revised/accepted: November 7, 2017; available online: January 31, 2018.

Editorial handling: Jorge Skármeta. 